NBER WORKING PAPER SERIES

SUPERSANCTIONS AND SOVEREIGN

DEBT REPAYMENT

Kris James Mitchener

Marc D. Weidenmier

Working Paper 11472

http://www.nber.org/papers/w11472

\author{
NATIONAL BUREAU OF ECONOMIC RESEARCH \\ 1050 Massachusetts Avenue \\ Cambridge, MA 02138 \\ June 2005
}

Mitchener: Department of Economics, Santa Clara University and NBER; kmitchener@scu.edu. Weidenmier: Department of Economics, Claremont McKenna College and NBER; marc.weidenmier@claremontmckenna.edu. We thank seminar participants at the NBER Summer Institute, Stanford, UC Irvine, and the $5^{\text {th }}$ World Cliometric Congress for comments and suggestions. We also thank Annalisa Yenne and Justin Jones for valuable research assistance, and the National Science Foundation, Leavey Fund, and the Dean Witter Foundation for financial support. The views expressed herein are those of the author(s) and do not necessarily reflect the views of the National Bureau of Economic Research.

(C2005 by Kris James Mitchener and Marc D. Weidenmier. All rights reserved. Short sections of text, not to exceed two paragraphs, may be quoted without explicit permission provided that full credit, including () notice, is given to the source. 
Supersanctions and Sovereign Debt Repayment

Kris James Mitchener and Marc D. Weidenmier

NBER Working Paper No. 11472

July 2005

JEL No. F10, F34, G15, N10, N20, N40

\begin{abstract}
Theoretical models have suggested that sanctions may be important for enforcing sovereign debt contracts. This paper examines the role of sanctions in promoting debt repayment during the classical gold standard period. We analyze a wide range of sanctions including gunboat diplomacy, external fiscal control over a country's finances, asset seizures by private creditors, and trade sanctions. We find that "supersanctions", instances where military pressure or political control were applied in response to default, were an important and commonly used enforcement mechanism from 1870-1913. Following the implementation of supersanctions, on average, ex ante default probabilities on new debt issues fell by more than 60 percent, yield spreads declined approximately 800 basis points, and defaulting countries experienced almost a 100 percent reduction of time spent in default. We also find that debt defaulters that surrendered their fiscal sovereignty for an extended period of time were able to issue large amounts of new debt on international capital markets. Consistent with policies advocated by Caballero and Dornbusch (2002) for Argentina, our results suggest that third-party enforcement mechanisms, with the authority to enact financial and fiscal reforms, may be beneficial for resuscitating the capital market reputation of sovereign defaulters.

Kris James Mitchener

Department of Economics

Leavey School of Business

Santa Clara University

Santa Clara, CA 95053

and NBER

kmitchener@scu.edu

Marc D. Weidenmier

Department of Economics

Claremont McKenna College

Claremont, CA 91711

and NBER

marc.weidenmier@claremontmckenna.edu
\end{abstract}




\section{Supersanctions and Sovereign Debt Repayment}

\section{Introduction}

Why do sovereign debt defaulters ever repay? Unlike debt issued by public corporations, sovereign debt contracts offer little legal recourse for creditors when a nation defaults. Nevertheless, the continued operation of sovereign debt markets and the fact that outright repudiation is rare suggest that incentives exist to induce repayment by sovereign borrowers. Argentina's 2001-2002 default and large write-down on $\$ 88$ billion of privately held debt is just one recent instance of sovereign debt default and subsequent renegotiation that has taken place regularly over the past two centuries (Reinhart and Rogoff, 2004). (Indeed, Argentina was a prominent defaulter in the 1890s as well.) Economists have suggested that the benefits of a good reputation or fear of economic sanctions might be sufficient to explain why borrowers repay (Eaton and Gersovitz, 1981; Bulow and Rogoff 1989a, 1989b; Kletzer and Wright, 2000; Obstfeld and Taylor, 2004). ${ }^{1}$ The widespread historical incidence of default raises important questions about the need for coordinated and coercive mechanisms to regulate sovereign debt default. $^{2}$

To shed light on these issues, this paper focuses on the role that sanctions played in response to sovereign debt default during the classical gold standard period. We first examine whether countries repaid because they experienced a persistent decline in trade during and after default (Rose, 2002). Some researchers have interpreted this as evidence that would be consistent with the presence of trade sanctions (Martinez and Sandleris, 2004). We then examine other sanctions that were available during this period to see if they were an effective means of enforcing debt repayment. These include private creditor sanctions and what we call "supersanctions" - instances where external military pressure or political and financial control was imposed on defaulting nations.

\footnotetext{
${ }^{1}$ Eaton and Gersowitz (1981) show that sovereign debtors repay because there are reputational costs if they renege. A country with a poor reputation might, as a result of default, be frozen out of international capital markets. English (1996) and Ozler (1993) provide some historical and empirical evidence on the importance of reputation in debt repayment. On the other hand, Bulow and Rogoff (1989a, 1989b) argue that reputation alone is insufficient for explaining debt repayment. They instead model repayment by defaulters as driven by sanctions or the threat of them. The precise nature of sanctions was not specified in their model, although they suggest that an obvious way to punish borrowers would be through restrictions on trade credit or an embargo. Weidenmier (forthcoming) examines the ability of trade credit sanctions to support debt repayment during the U.S. Civil War. Conklin (1998) provides some historical evidence of the use of sanctions in promoting debt repayment during the reign of Phillip II of Spain.

${ }^{2}$ For a literature survey on sovereign debt, see Eaton and Fernandez (1993) and Obstfeld and Rogoff (1996).
} 
In contrast to recent history, the historical record (Borchard, 1951; Kaletsky, 1985; Suter and Stamm, 1992) suggests that a broader range of sanctions may have been employed from 1870-1913. To our knowledge, sanctions of a military, economic, or political nature have never been empirically tested for this period, in part because they were believed by economists and historians to be rare and isolated episodes (Lindert and Morton, 1989; Lipson, 1989; Mauro and Yafeh, 2003; Suter and Stamm, 1992). ${ }^{3}$ Moreover, some policymakers have argued that the only effective sanctions that can be applied to defaulters are those by governments, and not by banks or individual creditors (Cabellero and Dornbusch, 2001; Kaletsky, 1985). This suggests that understanding how sanctions have been applied in the past may be instructive, even though the range of sanctions is perhaps narrower today.

Using an augmented gravity model of trade and a new database of nearly 9,000 bilateral trade pairs for the gold standard era, we test whether bilateral trade flows are associated with debt default. We do not find that, in general, trade between a creditor and a debtor country fell in response to a default during our sample period. Lack of evidence for the widespread existence of this effect suggests that governments and creditors may have had better methods for enforcing debt repayment during this earlier era. Indeed, we find evidence that supersanctions were a particularly effective and commonly used enforcement mechanism over the period 1870-1913. Even though they were applied selectively during the gold standard era (typically when the defaulting nation had strategic or military importance to one of the creditor countries), all nations that defaulted on sovereign debt ran the risk of gunboats blockading their ports or creditor nations seizing fiscal control of their country if they defaulted. We find that, conditional on default, the probability that a country would be "sanctioned" (either via supersanctions or seizures of assets by private creditors) was greater than 40 percent during the period 1870-1913. Moreover, roughly two-thirds of these sanctions took the form of gunboat diplomacy or the loss of fiscal sovereignty by the defaulting country, i.e. supersanctions. A statistically significant decline in trade as a result of default was also observed when gunboat diplomacy or fiscal control was used by creditor countries.

\footnotetext{
${ }^{3}$ For a discussion of the economic effects of sanctions since World War I, see Davis and Engerman (2003). Hogan (1906) surveys the use of minor interventions, called 'Pacific Blockades', during the nineteenth century. Fratianni (2004) examines how San Giorgio, a creditors' association formed by lenders to reduce the risk of debt repudiation, used various enforcement mechanisms to reduce the probability of default by the Republic of Genoa from 14071805.
} 
Consistent with the view that supersanctions were an effective means of altering behavior of defaulting nations, bond traders lowered their assessment of default risk in countries that were supersanctioned. We find that ex ante default probabilities (for a default on the principal) fell by more than 60 percent after the onset of supersanctions. Yield spreads declined approximately 800 basis points and defaulters experienced almost a 100 percent reduction of time spent in default. Only countries that surrendered their fiscal sovereignty for an extended period of time were able to issue large amounts of new debts on the London capital market. Consistent with what Caballero and Dornbusch (2002) have argued for restoring Argentina's reputation after its recent default, our results suggest that third-party enforcement mechanisms, with the authority to enact financial and fiscal reforms, may be beneficial for resuscitating the capital market reputation of sovereign defaulters.

Section II of the paper describes the nature of sovereign defaults during the gold standard era. Based on both the theoretical literature on sovereign default and the historical record, this section also describes the range of sanctions that creditors could take in response to default. Following the lead of recent empirical work on sovereign debt and trade, the next two sections test whether there is evidence that trade fell during and after a default. Section III presents a simple augmented gravity model of bilateral trade and describes the data used to test the model, and Section IV summarizes the empirical results. Section V broadens our investigation of sanctions, beyond their effects on bilateral trade, and examines whether supersanctions had an impact on ex ante default probabilities, yield spreads, and time spent in default. Section VI offers some concluding comments.

\section{Sovereign Debt Default during the Gold Standard Era}

\section{A. Enforcement Mechanisms}

The classical gold standard period is often described as the era of high bond finance since firms primarily financed their investment projects through debt. The issuance of sovereign debt by European countries and newly independent countries in other parts of the world, in particular Central and South America, was another prominent feature of this period. Creditor nations were primarily located in Western Europe and were led by Britain. French, German and Dutch capital 
played a secondary role. The majority of sovereign debt was issued on the London Exchange, both in terms of issues and size of issues (Clemens and Williamson, 2004). As Table 1 and Figure 1 show, another prominent feature of the classical gold standard period was that sovereign debt default was quite common.

Economists and historians have suggested a variety of coercive and coordinating mechanisms that may have been used to regulate sovereign debt default during the classical gold standard era. During this era, creditors in a few countries began to organize associations to protect their interests and seek settlements when sovereign borrowers defaulted. Most prominent was the Corporation of Foreign Bondholders (CFB), formed by British creditors in $1868 .{ }^{4}$ Although they offer no formal test, Mauro and Yafeh (2003) suggest that the CFB may have played a role in denying countries with poor reputations access to capital markets. They point out that the Corporation published valuable economic data on sovereign debt burdens and tax revenues to discourage investment in countries that did not repay their debts. The CFB also established creditor committees of British bondholders to facilitate debt settlements between lenders and defaulters and even worked with creditor associations in Paris and Berlin to prevent debt defaulters from borrowing in international capital markets, although collective action problems often prevented these groups from working together effectively. The fact that the CFB sometimes petitioned the British government to intervene and pressure a sovereign to repay or settle its debts also suggests that private creditor associations were not entirely effective at regulating debt defaults.

Although the CFB likely played a role in debt settlement and enforcement by punishing countries with poor reputations, other research suggests that reputation alone was insufficient to explain debt repayment during the classical gold standard. For example, Flandreau and Zumer (2004) find that interest rate spreads (interest rate of country $i$ that defaulted minus the interest rate on the 'risk-free' UK Consol) increased by 500 basis points following a default. One year after a debt settlement was reached, markets assessed a penalty of 90 basis points, which fell to 45 basis points, ten years after a default. Flandreau and Zumer (2004, p. 49) conclude, "while there is indeed a penalty for defaulting, this penalty turns out to be, over the medium run of a smaller order of magnitude than the savings associated with the amount of debt that has been

\footnotetext{
${ }^{4}$ Creditor associations in other countries were formed much later: France and Belgium in 1898, and Germany in 1927.
} 
repudiated. In other words, there was a clear incentive for governments not to repudiate their debt, but this incentive was too small to act as a systematic deterrent." Lindert and Morton (1989) also find little evidence that defaulters were charged higher interest rates in international capital markets.

In addition to reputation, creditors may have used sanctions to encourage repayment and discourage future default. One possibility, suggested by Bulow and Rogoff (1989a, 1989b), is that creditors punish defaulters by imposing restrictions on trade through tariffs or quotas or by denying countries access to trade credit. Rose (2002) examines the empirical evidence between trade and default, and suggests that countries repay their debts because trade falls during and after default. Examining data on sovereign defaults over the last forty years, he finds that bilateral trade between a creditor and defaulting country significantly declined ( 8 percent per year) subsequent to default. Moreover, the reduction in trade seems to persist for at least 15 years after the default. Although the effect is economically significant, Rose does not identify the precise mechanism that causes trade to shrink. He suggests that the measured decline in trade is consistent with the imposition of trade sanctions, such as restrictions in trade credit, but it could be also for some other reason altogether. ${ }^{5}$

The historical record suggests that, during the gold standard era, the range of government sanctions was broader than what has been used during the last half century. First, the use of military force or the imposition of foreign control over the fiscal and monetary administration of a country in response to a default, or what we call "supersanctions," were employed. Second, private creditors sometimes seized the assets of sovereign debt defaulters. These sanctions may have been used to coerce countries into repayment or to improve the capital-market reputation of sovereign defaulters. Table 2 provides a list of supersanctions and sanctions used by private creditors in response to sovereign debt default that occurred between 1870-1913. Panel A of Table 2 describes and identifies two types of supersanctions that existed during the classical gold standard period. They include: (1) episodes where gunboats were used (in response to

\footnotetext{
${ }^{5}$ Martinez and Sandleris (2004) have narrowly interpreted Rose's findings as evidence in favor of trade sanctions. They subjected Rose's data to further testing by examining whether trade in general, and not just with creditor nations, falls in response to default. Once trade with all partners is controlled for, they find no statistically significant decline in trade associated with creditor countries, and conclude that trade sanctions are not used to punish defaulters. To be fair, Rose (2002) also examines the general trade effect by looking at whether trade diversion occurred. That is, if trade dried up with the creditor country, perhaps more trade took place with non-creditors as a result. Moreover, their findings could also be interpreted as consistent with trade sanctions, because if trade shrinks for any reason, sovereigns might be more likely to repay.
} 
Venezuela's default in 1902-1903 and the repeated, threatened use of them in conjunction with the Roosevelt Corollary in Central America (see Mitchener and Weidenmier, forthcoming)); and (2) episodes that put debtor nations under "house arrest" by imposing foreign administrators on debtor nations and endowing them with the authority to collect customs and carry out fiscal administration (as in Egypt, Greece, Morocco, Santo Domingo, Tunis, and Turkey). Panel B of Table 2 provides a list of asset seizures by private creditors in response to debt defaults; these include private creditors seizing control of a sovereign debtor's railway assets and debtors ceding public lands to external bondholders.

\section{B. Should Sovereign Defaulters Have Feared Sanctions?}

Supersanctions and asset seizures by private creditors had obvious costs to defaulting countries. Despite these costs to defaulting countries, there is no empirical research we are of that systematically tests how such sanctions affected debt repayment. ${ }^{6}$ Rather, as we noted above, some historians and economists have tended to downplay the effects of sanctions on sovereign debtors because they were viewed as rare events. Many studies have suggested that, even though most governments felt an obligation to protect the property and safety of their citizens, they were mostly reluctant to intervene on behalf of creditors because this not only invited moral hazard on the part of creditors, but it often proved politically and economically costly. For example, it has been suggested that the British government was concerned that interventions violated sovereign immunity and undermined the confidence in newly-formed, democratic nations. Previous research has thus emphasized that the British Foreign Office maintained a non-interventionist position at least since the defaults of the early $1820 \mathrm{~s}$. But as Platt (1968) and Lipson (1985) argue, exceptions to this policy were often made for strategic interests.

Table 3 shows that there were 18 episodes of sanctions during the gold standard period 12 cases of supersanctions and six where private creditors acquired assets of sovereign debt defaulters. The assessment that this figure represents a quantitatively unimportant number can

\footnotetext{
${ }^{6}$ Kaletsky (1985, p. 40) asserts that the "nineteenth century's gunboats" were effective "in bringing defaulters to their knees," but does not formally test this hypothesis. Although Suter and Stamm (1992) note that sanctions have rarely been used to regulate debt default, they also point out that most debt sanctions were employed during the gold
} 
only be obtained if one examines these episodes unconditionally and ignores the history of default during the gold standard era shown in Table 1. As the summary statistics displayed in Table 3 show, conditional on default, the probability of facing sanctions was quantitatively significant regardless of whether default is measured in terms of number of episodes, number of countries, number of years in default, or the size of defaults. In terms of default episodes, 18 out of 43 defaults during the gold standard period, or 42 percent, were subjected to supersanctions or private creditor asset seizures. Of the countries that defaulted during the gold standard era, 16 out of 25 (or 64 percent) were sanctioned, and 9 out of 11 countries (or 81 percent) that defaulted multiple times during the gold standard period were sanctioned. Sovereign debt defaulters were sanctioned a combined 131 years during the classical gold standard period. ${ }^{7}$ Finally, in terms of the size of defaults, we estimate that more than 45 percent of all defaulted debt during the classical gold standard was sanctioned by creditors or the leading creditor powers. ${ }^{8}$

Tables 2 and 3 further elucidate the types of sanctions used by creditors and governments to punish debt defaulters. Supersanctions were the most common form of sanction during the era of bond finance. Gunboat diplomacy or the establishment of international financial control was used in 12 out of 43 defaults (28 percent) during the era of bond finance, and the average length of outside fiscal control by foreign powers was approximately 11.25 years. ${ }^{9}$ For every year a country was in default, there was more than a one and four chance that it would be subjected to military intervention by a creditor nation or the establishment of an international financial council that administered various aspects of the debtor's finances. Private creditor sanctions were quantitatively less important than supersanctions during the gold standard period, occurring in 6 of the 43 defaults (14 percent), and accounting for almost 6 percent of the debt issued.

standard period. However, they do not formally test whether sanctions were a commonly used tool during this historical era.

${ }^{7}$ This figure represents a lower bound because we assume that asset seizures by private creditors, in response to a debt default, were a one-time event. If we count episodes where sovereign defaulters turned over assets for a specified period of time (i.e., Grace Contract in Peru), then the number of years defaulters were sanctioned rises to more than 170 years.

${ }^{8}$ To compute this figure, we gathered annual data from the Investors' Monthly Manual and secondary sources, and calculated the total outstanding defaulted debt (unredeemed debt at par value) over the entire sample period. For Tunis, Morocco, and Servia, we used estimates from Correa (1926), Ling (1967), Stone (1999), and The Times (London). The percent of defaulted debt supersanctioned is about 1.5 percent higher if we use the Annual Reports of the Corporation of Foreign Bondholders to compute the amount of debt defaulted by Peru in 1880s as opposed to the number reported in the Investor's Monthly Manual.

${ }^{9} \mathrm{We}$ calculated this figure by averaging all episodes of gunboat diplomacy and financial control shown in Table 2. 
The simple statistical evidence presented in the tables suggests that sanctions may have been employed frequently enough on defaulting nations during the classical gold standard era that they may have served as a credible threat to deter future default or to cleanse the reputation of defaulters. Before turning to an examination of how important sanctions were for regulating debt default, we first consider whether there is evidence that trade fell in response to default - a result that would be consistent with the operation of a third type of sanction, trade sanctions, during the gold standard period. We do so, in part, because these sanctions have received considerable attention from economists analyzing more recent sovereign debt defaults (Rose, 2002; Martinez and Sandleris, 2004).

\section{Modeling Bilateral Trade during the Gold Standard}

\section{A. Estimation Strategy}

To examine how default affected bilateral trade in the gold standard era, we construct a gravity model of international trade a la Rose (2002). There are two reasons to think that this test might be particularly well suited to our sample period. First, since 1870-1913 predates the existence of official creditor programs, we do not have to worry about disentangling changes in trade flows that may result from the involvement of multilateral institutions. Second, the gold standard era is less prone to collective action problems that arise in attempting to enforce tradecredit sanctions - one type of sanction that Rose (2002) suggests may have been important for the more recent period of debt default. Since the House of Baring was the world's largest broker of trade credit at the time and a large issuer and investor in foreign government debt, it would have been easy for it to act unilaterally and punish defaulters by denying them access to trade credit.

The gravity model is a very simple empirical relationship meant to capture the main effects of trade: mass and distance. As in a standard gravity equation, mass (measured here by the size of countries) is proportional to trade whereas distance varies inversely. We augment it with an additional set of covariates to capture other influences on bilateral trade. The basic estimation equation takes the following form: 
(1) $\ln \left(\right.$ BITRADE $\left._{\mathrm{ijt}}\right)=\beta_{0}+\beta_{1} \ln \left(\mathrm{RR}_{\mathrm{i}} \mathrm{RR}_{\mathrm{j}}\right)_{\mathrm{t}}+\beta_{2} \ln \left(\mathrm{Pop}_{\mathrm{i}} \mathrm{Pop}_{\mathrm{j}}\right)_{\mathrm{t}}+\beta_{3} \ln \mathrm{D}_{\mathrm{ij}}+\beta_{4} \operatorname{Lang}_{\mathrm{ij}}+\beta_{5}$ Bord $_{\mathrm{ij}}+$

$$
\begin{aligned}
& \beta_{6} \text { Gold }_{\mathrm{ij}}+\beta_{7} \text { Lndlck }_{\mathrm{ij}}+\beta_{8} \ln \left(\text { Area }_{\mathrm{i}} \mathrm{Area}_{\mathrm{j}}\right)+\beta_{9} \mathrm{CU}_{\mathrm{ij}}+\text { CCREDITOR }_{\mathrm{ijt}}+ \\
& \Sigma_{\mathrm{K}} \theta_{\mathrm{k}} \text { CREDITOR }_{\mathrm{ijt}-\mathrm{k}}+\Sigma \gamma \operatorname{SEFAULT}_{\mathrm{tij}}+\Sigma_{\mathrm{M}} \gamma_{\mathrm{m}} \text { DEFAULT }_{\mathrm{ijt}-\mathrm{m}}+\varepsilon_{\mathrm{ijt}},
\end{aligned}
$$

where $i$ and $j$ denote countries, $t$ denotes time, and other variables are defined as:

- BITRADE $E_{\mathrm{jit}}$ denotes the average bilateral trade between $\mathrm{i}$ and $\mathrm{j}$ at time $\mathrm{t}$;

- RR is railroad track miles;

- Pop is population;

- D is distance between $i$ and $j$;

- Lang is binary variable which is unity if $i$ and $j$ have a common language;

- Bord is a binary variable which is unity if $i$ and $j$ share a border;

- Gold is a binary variable which is unity if $i$ and $j$ both are on the gold standard;

- Lndlck is the number of landlocked countries in the country-pair dyad $(0,1$, or 2$)$;

- Area is the land mass of the country in square miles;

- $\mathrm{CU}$ is a binary value if both countries are part of either the Latin or Scandinavian currency unions;

- CREDITOR is a binary variable which is unity if $i$ or $j$ is in default at time $t$ and one of the countries is Britain;

- DEFAULT is a binary variable which is unity if either $\mathrm{i}$ or $\mathrm{j}$ is in default at time $\mathrm{t}$;

- $\mathrm{K}$ and $\mathrm{M}$ are lags of unknown length;

- $\beta$ are estimated coefficients;

- and $\varepsilon$ is a white noise error term capturing other influences on bilateral trade.

The key coefficients of interest are the $\theta \mathrm{s}$, which show the effect of default on bilateral trade between the creditor and defaulter, and the $\gamma \mathrm{s}$, which show the general effects of default on trade. Including both CREDITOR and DEFAULT in equation 1 enables one to disentangle the direct effect of a default on creditor-borrower trade from the effects on trade between the defaulted sovereign nation and all trading partners. We estimate equation (1) with both fixed-effects and random-effects panel techniques. The fixed effects or within estimator is equivalent to adding a complete set of country pair-specific intercepts to the estimating equation. While fixed effects ensure that the estimation of $\theta$ and $\gamma$ are consistent, they may not be efficient. The random effects estimator can yield more efficient estimates, but it does not apply in as wide a range of circumstances as the fixed effects estimator. We also employ specifications using a full set of year dummies. 
To estimate equation 1, we assembled a new, extensive database of annual bilateral trade flows using a consistent set of British statistical sources published by the Board of Trade. In particular, we relied on numerous volumes of the Statistical Abstract for the United Kingdom and the Statistical Abstract for the Principal and other Foreign Countries for the period 1870 to 1912. Our new database significantly improves upon the only other database that has extensive bilateral trade data for the gold standard period (Barbieri, 1996) in that it includes many more country pairs as well as more depth in the time-series dimension. Our data set is fairly wide ranging and captures most of the world's trade during the gold standard era. There are roughly 9,700 observations and 322 country pairs (dyads). Relative to Barbieri (1996), the coverage of defaulting countries is also improved. Our data set includes 23 out of the 25 countries (92 percent) that defaulted during the gold standard period compared to Barbieri's, which covers 19 out of 25 countries (or 76 percent). We were able to collect data for 35 out of 43 (81 percent) gold standard default episodes. Defaulters include major borrowers from around the world such as Argentina, Egypt, Greece, and Turkey, in addition to less prominent defaulters in Central and South America. ${ }^{10}$ On the other hand, Barbieri's database covers 30 out of 43 (70 percent) episodes of default. In addition, our sample has much greater coverage of the creditor-defaulter trade relationship that can be used to test for the existence of trade sanctions. Our new database has bilateral trade data between the U.K. and sovereign debtors for 21 out of 43 default episodes (49 percent). The Barbieri sample only has U.K. bilateral trade data with debtors for 8 out of 43 (19 percent) default episodes during the gold standard period. Since our sample is quite representative of defaults, it thus permits an analysis of trade and default during this earlier period of globalization. These trade data were converted into current pounds using average annual exchange rates from Global Financial Data (GFD) and Schneider et. al. (1991-1997). The data reported in the Statistical Abstract required a "currency adjustment" because trade for foreign countries was computed based on a "long-run" exchange rate that often deviated from the

\footnotetext{
${ }^{10}$ Out of 8 default episodes for which we do not have data, four are for Santo Domingo. The British statistical publications do not separately distinguish Santo Domingo's trade from Haiti during the gold standard period. Of the episodes listed in Table 1, those for which we lack trade data are: Nicaragua (1827), Tunis (1867), Costa Rica (1874), and Morocco (1903-1904).
} 
current market rate. ${ }^{11}$ After adjusting the data to reflect current market exchange rates, we deflated the trade data using the U.K. PPI expressed in $£ 2000$.

Although we would like to have included GDP to measure "mass," reliable annual estimates for a wide range of non-OECD countries prior to 1914 (including the sovereign defaulters) are scarce. We therefore used several other proxies to capture mass: area in square miles, population, and total railroad miles. These data series are from Banks (1976) and the Investors' Monthly Manual. Data on (log) distance in miles are from Rose (2002). Data on when countries went onto the gold standard and joined the Latin and Scandinavian Monetary Unions are from Bordo and Kydland (1995), Bordo and Schwartz (1995), Flandreau and Maurel (2002), Ferguson and Schularick (forthcoming), Meissner (forthcoming), and Officer (2004). Default dates for sovereign debtors were collected from various issues of the Corporation of Foreign Bondholders Annual Report.

\section{Measuring the Effects of Sanctions on Trade}

\section{A. Empirical Estimate of the Effects of Default on Trade}

Table 4 displays pooled regressions using ordinary least squares and clustered standard errors. Column 1 shows a bivariate regression of bilateral trade on default, and as predicted by the trade sanctions literature, the sign is negative. Column 2 places the default variables alongside a very simple gravity model and adds three lags of the default dummy. Adding (log) distance and $(\log )$ area produces results that are consistent with gravity model predictions: distance reduces bilateral trade and mass increases it. When we consider the sum of the coefficients on default and its lags, trade declines in response to default. The sum of the current and lagged default coefficients remains negative when either the log product of population (column 3) or the log product of railroad miles (column 4) is added. ${ }^{12}$ The overall negative effect of default on trade does not change when year dummies are added (column 5) or when additional lags of the default variable are included. However, the sum of the current and lagged default

\footnotetext{
${ }^{11}$ In most cases, the long-run exchange rate did not deviate much from the market rate. This is especially true for countries that were on the gold standard. Most of the large deviations from the market rate were observed for countries that had floating rates or temporarily left the gold standard for a well-understood emergency (i.e. war).

12 The default variables in column 3 are jointly statistically significant at the five-percent level.
} 
variables is not significant at the five or 10-percent levels of significance once the log product of railroad miles is included (columns 4 and 5).

Table 5 improves upon the initial regressions by including other influences affecting trade (as described in equation 1). The regressions also exploit the panel nature of the data by estimating random and fixed effects gravity models - the latter controlling for omitted bilateralspecific effects. The R-squared in the fixed effects model (when distance can be included) is approximately 0.4 , suggesting that our gravity model predicts a significant amount of variation in the bilateral trade flows. Moreover, the signs on the coefficients are largely as hypothesized and are, for the most part, statistically significant. There is greater trade between countries with more mass, as measured by the log product of population and the log product of railroad miles, although the empirical results suggest that larger countries, as measured by area, trade significantly less in three of the four specifications. The negative sign of the coefficient for area may be driven by multicollinearity between the different measures of mass and area. However, this is not a problem for our main variable of interest (default). On the other hand, countries that are further in distance from each other have lower bilateral trade. Being a landlocked country does not seem to have a statistically significant effect on trade. We also find that those countries that border each other or are both on the gold standard have larger trade flows. ${ }^{13}$ Membership in a currency union does not have a statistically significant effect on trade, however. This may simply be explained by the fact that we have only a handful of observations on bilateral trade for members of the Scandinavian Currency Union, the only monetary union in our sample.

For the most part, these results are consistent with Rose (2002), Martinez and Sandleris (2004), and other models estimating bilateral trade. However, our empirical estimates differ from research using data from the second half of the $20^{\text {th }}$ century in that we discern no decline in trade as a result of default. In fact, in all four specifications shown in Table 5 (with or without year dummies), default has a statistically insignificant coefficient in the current period, and it enters with a positive coefficient in all four specifications. Moreover, the sum of the effect (including

\footnotetext{
${ }^{13}$ Lopez-Cordova and Meissner (2003) find that joining the gold standard increased trade by nearly 30 percent during the period 1870-1913. Bordo and Rockoff (1996) find that countries on the gold standard were charged lower interest rates in international capital markets.
} 
lags) is not significantly different from zero. ${ }^{14}$ The result suggests that trade sanctions may not be operating during the gold standard period. ${ }^{15}$

To test this result further, Table 6 includes an additional indicator variable to capture bilateral trade between the creditor and the defaulting country when the sovereign borrower is in default. We used Britain as the creditor country. Including this variable allows us to distinguish between an overall change in trade as a consequence of default and an effect that is particular to the creditor-debtor relationship. A negative sign on the creditor-debtor indicator variable would be consistent with the hypothesis that trade sanctions were applied during the gold standard era. However, as the results in all four columns show, the effect has the wrong predicted sign (positive) and is statistically significant. ${ }^{16}$ We tried alternative specifications using a broader set of creditor countries (Germany, France, Holland, and Britain), but the result on the creditordefaulter indicator variable was still positive and statistically significant. The sum of the current and lagged default variables are significant at the five-percent level in the fixed and random effect specifications until year dummies are added to the models. With the addition of the year dummies, the default variables are no longer significant at even the 25 -percent level. ${ }^{17}$

Overall, the results from Tables 4-6 cast doubt on the idea that trade declined in response to default during the gold standard era - at least when it is analyzed in a similar fashion to more recent episodes of default (i.e., Rose 2002, and Martinez and Sandleris 2004). As the previous section of the paper suggests, one possible explanation for why our results differ from the recent period of sovereign debt default is that creditors punished defaulters using other types of sanctions. Examining the Annual Reports of the CFB and the Investors' Monthly Manual, we have been unable to uncover any historical evidence supporting the proposition that quotas, tariffs, or trade-credit restrictions were systematically applied to defaulters during the gold

\footnotetext{
${ }^{14} \mathrm{We}$ also experimented with changing the number of lags in the fixed and random effects models. Even when we change the lag lengths, we do not find a statistically significant decline in trade after default.

${ }^{15}$ As a robustness check, we estimated the gravity models using the trade data as it appears in the UK Statistical Abstracts. The results are reported in Appendix B. Our main finding reported in the text, that trade does not fall in response to a debt default, is robust even if we do not adjust for deviations from the "long-run" exchange rate.

${ }^{16}$ The results for debt default are robust to including exchange rate volatility and individually dropping area, population, or railroad miles from the fixed and random effects specifications. We also replaced the default dummy with the log of the size of the debt default, estimated using data from the IMM. We also estimated the model using more lags on the default variable. The results shown above were robust to all these changes in the specification. Details are available from the authors by request.

${ }^{17}$ We also considered specifications controlling for left-hand censoring of the bilateral trade variable. A randomeffects tobit model did not change the results presented here. As an additional robustness check, we re-estimated the
} 
standard era. With respect to trade-credit restrictions, we have, in fact, found that the House of Baring unsuccessfully lobbied the British government in the $1860 \mathrm{~s}$ to intervene and force Guatemala to repay its long defaulted debt obligations (Ziegler, 1988). Since it was the largest provider of trade credit, this suggests that this mechanism must not have been sufficient to induce defaulters to change their behavior. Our findings do not rule out the possibility that trade may have been curtailed through non-trade-related sanctions during the gold standard period - an issue to which we now turn.

\section{B. Trade and Supersanctions}

As described in Section III, there were approximately 12 episodes of default during the classical gold standard era, which were met with more drastic responses by creditor countries. In these instances, creditors were sometimes able to convince their governments to intervene on their behalf and force repayment through the use of gunboat diplomacy or a fiscal takeover of the defaulting nation. This often proved possible because the government's political or strategic objectives were aligned with the motives of private creditors residing in those countries.

One might expect that if a debtor country's finances are taken over by a creditor country or if it is forced to make payments because gunboats are sitting in its harbors, then trade flows might have differed from conventional defaults. Thus, as an extension, we consider how trade was affected by five of the most important episodes of supersanctions: the blockading and bombardment of Venezuela in 1902; the imposition of the Roosevelt Corollary in Central America in 1904; and the establishment of British control over Egyptian finances in 1883, European control of Turkish finances in 1881, and European control over Greek finances in 1898. In each of these cases, nations had defaulted on their debt and were unwilling or incapable of making payment, and in each case, creditor governments responded by taking away sovereignty or using gunboats to enforce debt claims.

Episodes of gunboat diplomacy are perhaps the cleanest type of a supersanction to test in a gravity model framework because the expected sign on the trade coefficient is unambiguous. Two of our five cases fit this category. One case of gunboat diplomacy occurred in 1902, when

fixed- and random-effects models as well as the tobit specification using Barbieri's (1996) trade database for the gold standard period. Details are available from the authors. 
European countries used a naval blockade and gunboats to force Venezuela to come to terms on its defaulted debt. Venezuela experienced a revolution in 1898 that lasted more than two years. During that time, substantial foreign property was destroyed and the government ceased payments on its debt. Britain, Germany, and Italy blockaded the ports of La Guiara and Puerto Cabello and seized customhouses when President Castro of Venezuela refused to reply to foreign claimants. Germany then unilaterally bombarded the fort at San Carlos. Castro acquiesced in February 1903, and agreed to arbitration and a gradual liquidation of Venezuelan debt. Under the terms agreed to at the Hague conference in 1904, the European countries that blockaded Venezuela were given the right to a preferential payment of 30 percent of claims since they had footed the bill and provided the force that resulted in benefits to all creditors. Claims of countries that did not participate in the military occupation, including the United States, were subordinated.

A second case of gunboat diplomacy came a few years later and covered a broader geographical area in the same region. Signaling a dramatic shift in its relations with its neighbors, and at least partly in response to the Venezuelan episode, the Roosevelt administration outlined a new interventionist policy in 1904, which came to be known as the Roosevelt Corollary to the Monroe Doctrine. ${ }^{18}$ The United States would police the nations of Central America, northern South America, and the Caribbean, and protect the interests of European investors by using its regional power to ensure that sovereign debts of these Latin American nations would be honored. By proposing a larger role for the U.S. in the region, Theodore Roosevelt aimed simultaneously to assert U.S. dominance in the region (which included the construction of the Panama Canal) and to check any military expansion of Europeans. As Roosevelt explained, the U.S. would henceforth play the role of enforcing creditors' claims in Central America, the Caribbean, and the northern reaches of South America:

If a nation shows to act with decency with regard to industrial and political matters, if it keeps order and pays its obligations, then it need fear no interference from the United States. Brutal wrong-doing, or an impotence which results in a general loosening of the ties of civilized society, may finally require intervention by some civilized nation, and in the Western

\footnotetext{
${ }^{18}$ See Mitchener and Weidenmier (forthcoming) for more details on this episode and an examination of the effects of this policy on sovereign debt prices.
} 
hemisphere the United States cannot ignore the duty. (New York Times, "The President's Annual Message," 7 December 1904, p. 4.)

To estimate the effects of gunboat diplomacy on the trade of countries that defaulted, we coded an additional indicator variable that takes on values of one during years in which the creditor(s) intervened. In contrast to the results shown in previous tables, we find a negative and statistically significant effect on trade for these two cases of gunboat diplomacy (Table 7). Given the presence of gunboats in its harbor at the end of 1902, it is not terribly surprising that Venezuela's bilateral trade was disrupted and fell in response to the military actions of Italy, Germany, and Great Britain. Table 7 shows that trade for Venezuela fell approximately 30 percent in both the fixed and random effects models as a result of the international blockade. Moreover, the actions had the intended effect, at least in the eyes of the private individuals who held Venezuelan debt, in that it forced Venezuela to agree to negotiate a debt settlement in 1903.

We also find that the implementation of the Roosevelt Corollary (RC) reduced bilateral trade. The fixed effects model estimates that bilateral trade between countries in Central America and the United States fell by 31 percent while the random-effects model estimates the drop in bilateral trade to be slightly greater than 29 percent. The negative sign associated with the Roosevelt Corollary suggests that U.S. foreign policy may have diverted bilateral trade in the region, considering that overall trade in the area increased during this period. When we recode the RC dummy variable to include all bilateral trading partners for the Central American Republics, the dummy variable in Table 7 remains negative and significant. The coefficient on the RC dummy shows that overall trade fell by 11 percent, although the point estimate is not statistically different from the 30 percent decline in bilateral trade with the U.S. ${ }^{19}$ This suggests that the Roosevelt Corollary did not significantly divert Central American trade away from the United States to other countries.

We next test whether imposing a foreign administrative body to oversee fiscal and financial policies of debtor nations affected trade flows. However, for this type of supersanction, whether trade should increase or decrease as a result of it is ambiguous. On the one hand, creditor countries exercising fiscal control over a debtor could change the procedures or methods for collecting customs duties or other sources of revenues and/or bring in armies or officials to restore order and ensure that trade continues, thus increasing trade. On the other, creditor

\footnotetext{
${ }^{19}$ Details are available from the authors by request.
} 
countries imposing fiscal control could choose to punish defaulters, and make an example of them by allowing trade to suffer.

We report the results for three of the fiscal interventions described in Table 2: Egypt, Greece, and Turkey (Ottoman Empire). After a protracted period of default, the misuse of the receipts from foreign loans, and constant financial disorder, in 1881 European powers seized control over the administration and collection of Turkish finances. The Decree of Mouharrem articulated the debt adjustment reached with foreign creditors in Turkey. It was issued as a municipal law, but was effectively a bilateral agreement with its foreign creditors whereby their agents would assume the collection of revenues. The Ottoman Debt Council was composed of representatives of bondholders from creditor countries (with official governmental support of the creditor nations), and was charged with the administration, collection, and encashment of the revenues that were ceded to it for the payment of debt (Borchard, 1951).

Egypt came under British control in 1882 following a large debt default in 1876. Platt (1968) and others attribute British intervention to the violation of property rights of some U.K. nationals in Alexandria. More recently, Ferguson (2004b) suggests that one reason Britain intervened and introduced financial reforms in Egypt was because Prime Minister Gladstone was a large investor in the country's sovereign debt. Regardless of the rationale for intervention, a debt settlement was agreed to in 1883 and Britain was given control of Egypt's purse strings for the remainder of the gold standard period.

In 1898, Greece also came under foreign financial control after it defaulted on its war indemnity resulting from the Greco-Turkish War of 1897. As terms of the peace treaty, European powers were given authority to assume the administration of revenues on behalf of existing creditors and to effectuate payment of the war indemnity. Germany had been the major player in arranging the protection of foreign bondholders' interests, and it was given authority by the other European countries to come to terms with Greece about the operation and control over Greek finances as well as the terms of debt settlement. These were laid out in a Greek municipal law of March 10, 1898, but according to Borchard (1951), it was a sovereign act in appearance only.

As Table 7 shows, supersanctions had a negative and significant effect on trade in Egypt, Greece, and Turkey in five out of the six specifications. For Egypt, trade declined approximately 47 percent in the fixed-effects specification and 42 percent in the random-effects model with the implementation of the supersanction. For Greece, trade fell by approximately 20 percent in both 
the fixed- and random-effects specifications. For Turkey, trade fell by nearly 26 percent in the fixed-effects specification after the onset of foreign financial control. Only the random-effects specification for Turkey does not show a statistically significant decline in trade. The results suggest that creditors punished defaulters for not paying their debts. One possible explanation for the fall in trade is that defaulting governments were no longer able to borrow in international capital markets on a large scale to finance personal consumption and the construction of lavish palaces through imports (i.e., Egypt and Turkey). Indeed, historians have pointed to wasteful spending and consumption purchases by ruling elites as an important factor that caused the debt defaults (Wynne, 1951). The decline in trade may also be explained by a rise in smuggling as merchants tried to avoid paying customs duties with the establishment of a more efficient tax collection service. These results suggest that supersanctions had a negative and statistically significant effect on trade. However, outside of these episodes of supersanctions, we find little support in the historical record or evidence from the gravity model that supports the hypothesis that trade sanctions operated during the gold standard era. Therefore, we now turn to examining ways in which other sanctions may have acted as credible threats to deter default or cleanse the reputation of borrowers.

\section{Sanctions and Capital Market Reputation}

Supersanctions constrained the behavior of defaulting governments and ruling elites and may have altered capital market beliefs about the willingness of these countries to pay their debts. By establishing military or economic control over these countries, creditors effectively placed defaulting governments under "house arrest": they lost the ability to make fiscal decisions without foreigners having a say. This section first describes institutional changes that took place in several instances where defaulting governments ceded control of their finances, and discusses how military interventions led to debt settlement. We then analyze the response of capital markets to supersanctions by examining ex ante and ex post yields on sovereign default.

\section{A. Institutional Change under "House Arrest"}


A committee of foreign bondholders, backed by the military power of the leading creditor nations (U.K., France, and Germany), administered customs collection and controlled the finances after defaults in Greece, Turkey, and Servia. Egypt, Liberia, Morocco, Santo Domingo, and Tunis also ceded authority to foreign creditors, but in these cases it was to a single country that had tacit or formal support from other creditor nations to take control. In most of these episodes, committees were organized to regulate defaulters and ensure that they adhered to their debt settlements. This meant that tax revenues from import and export duties were pledged for the payment of defaulted debts, the terms of which had been negotiated by foreign authorities.

In Egypt, foreign financial control significantly changed fiscal administration and tax collection. Egypt's external debt increased fourfold in less than twenty years under the rule of Khedive Ismail Pasha. From 1863 until the mid 1870s, the Khedive used external debt to build bridges, a road system, canals, and Cairo. Egypt's spending eventually exceeded its revenues, and the Khedive was forced to issue new debt in London to cover previous debts. After several failed attempts to curb government expenditures, a Commission of Inquiry in 1878 by the Egyptian Assembly recommended a series of reforms, including restrictions on the power of the Khedive. Egyptian nationalists deposed Pasha in 1879 and a new ruler came to power two years later. Order broke down in the country and Britain intervened following the murder of some European citizens. But it was the persuasive powers of creditors, including the British prime minister, that proved critical for Britain's decision to take control of Egypt (Ferguson, 2004a).

The British administration in Egypt established an efficient tax collection system and restored fiscal discipline. The power of the Egyptian assembly to authorize spending was limited, and Britain was able to negotiate a debt settlement for Egypt by 1883. Nearly a decade after the debt workout, the ratio of government debt to tax revenue had been cut in half from 10:1 to 5:1. Fiscal reform attracted additional foreign capital, and Egypt regained access to capital markets borrowing at approximately half the rate of interest it had paid before Britain took control of the country's finances. Approximately 40 million dollars in new capital flowed into the country. Roads, railroads, and canals, including the Aswan Dam, were constructed using funds from tax revenues and new debt issues placed on international capital markets. The railway network expanded by a factor of four and the area available for cultivation increased by 50 percent (Ferguson, 2004a). Ferguson (2004a, p. 221) summarized the effects of British administration on Egypt's finances: 
In many ways, there was a modern quality to what happened. The British administration of Egyptian finances had much in common with an International Monetary Fund mission or rather the way an IMF mission would operate if it could call on the Royal Navy to enforce its prescriptions. Evelyn Baring, later Lord Cromer, ran Egypt's finances much like a modern structural adjustment program. The results were a fiscal triumph.

In the case of Greece, the establishment of an international financial commission also brought much needed fiscal reform to the country and enhanced its borrowing power. Prior to 1914, Greece used international capital markets to finance several wars in the years prior to 1914 that increased its boundaries by 68 percent. Foreman-Peck (1995) notes that Greece spent 193.7 million drachmas on its military between 1905 and 1911, and an additional 411 million drachmas on wars in the Balkans. Turkey, on the other hand, negotiated deals with France and Germany for the building of railroads in Mesopotamia and Iraq in exchange for concessions. Great Britain and Russia closely monitored railroad building in the Ottoman Empire because the two powers feared that a large railroad network in the Middle East might infringe on their territorial ambitions in the region. Although the channeling of funds into the construction of new railroads and infrastructure brought some benefits to Egypt, Greece, and Turkey, these supersanctions were not without costs, in particular, sovereignty. The governments of these countries lost control of their purse strings, and were placed under "house arrest" for 32, 15, and 31 years, respectively. ${ }^{20}$

\section{B. Estimating Ex Ante and Ex Post Returns for Supersanctioned Debt}

The historical evidence suggests that supersanctions may have improved the credit reputations of defaulters. We examine this question by comparing the ex ante default probabilities of supersanctioned countries using all available data on issue prices of sovereign debt before and after the imposition of a supersanction. We collected issue prices (IPO prices) for the supersanctioned countries listed in Table 2 (Costa Rica, Egypt, Greece, Nicaragua, and Turkey) using data from the Investor's Monthly Manual and London Stock Exchange Yearbook. The other countries listed in the table (Guatemala, Liberia, Morocco, Servia, Santo Domingo,

\footnotetext{
${ }^{20}$ For a brief discussion of tax revenue pledges by a defaulter as a type of sanction, see Obstfeld and Rogoff (1996).
} 
Tunis, and Venezuela) renegotiated their debts with creditors, and did not issue new debt on the London stock exchange prior to World War I, so no IPO prices were available. ${ }^{21}$

We estimate ex ante default probabilities for two different types of default: (1) total default (default on the principal), and (2) mild default (where the sovereign only reneges on the interest). A model of the expected rate of return for a bond issued by country $i$ is a weighted average of the contractual return and the default return. The model can be written as:

$$
\mathrm{R}_{1}(1-\mathrm{p})+\mathrm{R}_{2}(\mathrm{p}) \geq \mathrm{R}_{\mathrm{UK}}
$$

where $R_{1}$ is the ex ante internal rate of return at the time of issue, $R_{2}$ is the rate of return if country $i$ defaults on its debt, $\mathrm{R}_{\mathrm{UK}}$ is the return on risk-free UK Consols, and $\mathrm{p}$ is the probability of default. In our equation for ex ante default probability, we assume that investors are risk neutral and that the rate of return on the bonds of country $i$ is greater than the return on risk-free UK Consols, $\mathrm{R}_{1}>\mathrm{R}_{\mathrm{UK}}$, since British Consols were the preeminent debt issue of the gold standard period. For a total default, equation (2) becomes

$$
\mathrm{R}_{1}(1-\mathrm{p})-100(\mathrm{p}) \geq \mathrm{R}_{\mathrm{UK}}
$$

The -100 reflects the complete loss of principal in the event of default. In the case of a mild default, we assume that country $i$ defaults on its interest payments, but not the principal. In this case, Equation (3) is re-written as:

$$
R_{1}(1-p)+0(p) \geq R_{U K}
$$

To compute an ex ante measure of default probability, we only considered debt with a maturity greater than ten years because our proxy of the risk-free rate, British Consols, were long-term perpetuity bonds. In addition, all of the bonds in our sample are denominated in sterling except for Nicaragua, which issued new debt on the Paris Bourse in 1909. Since our sample of bonds is denominated in sterling, currency risk is (practically) eliminated in equation (2), which is

\footnotetext{
${ }^{21}$ These omitted countries were never big issuers of debt, especially in comparison to more prominent defaulters such as Egypt, Greece, and Turkey. As we show below, creditors still viewed supersanctions favorably and their debt traded at higher prices (lower risk premiums) after they were supersanctioned.
} 
otherwise a common problem in measuring default risk in modern financial markets. We then calculated ex ante default probabilities using equations (3) and (4).

Table 8 shows the average ex ante default probability for each country. Four out of the five countries in our sample experienced a large drop in their ex ante default probability using either of the two measures. Ex ante default probabilities rose only in one case - when Nicaragua issued new debt in 1909 following a bloody war with several other Central American republics. Table 9 reports the percentage reduction (increase) in the ex ante default probability for each of the eight countries in our sample. Overall, we find that ex ante default probabilities dropped nearly 42 percent for a mild default and 63 percent for a complete default. The decline in the ex ante default probability is greatest for Egypt, Greece, and Turkey, countries that individually issued more than 15 million pounds of new debt and were each supersanctioned for more than 15 years. The empirical evidence suggests that credit risk was lower for supersanctioned countries that surrendered their fiscal sovereignty for a long period of time. The establishment of external committees that monitored customs collections in Egypt, Greece, and Turkey may have sent a signal to financial markets that these countries would faithfully service their debts.

We tested the null hypothesis that ex ante default probabilities were equal in the presupersanction period and the period after the supersanction was imposed. We can easily reject (at the one-percent level) the null hypothesis that the difference in default probabilities are equal for both measures of default probability. The response of the bond markets is particularly interesting since one might expect countries that had previously defaulted to have had much higher ex ante default probabilities when they issued new debt in international capital markets; the fact that default probabilities fell for this particular sample suggests that supersanctions had powerful effects on the way bond market participants assessed risk. In summary, the evidence from the IPO data suggests that supersanctions significantly improved lending prospects for emergingmarket debtors during the gold standard period.

We next examine yield spreads of long-term bonds to provide an ex post measure of the effects of supersanctions on country risk before and after the implementation of supersanctions. We compute "country risk" for a sample of defaulters during the gold standard, measured as the yield on a representative sovereign bond minus the yield on the "risk-free" British consol in the pre-supersanction and supersanction periods. Debt issues that actively traded on the London stock exchange and had a maturity length of greater than ten years were selected as the 
representative debt instrument for the supersanctioned countries in the analysis. Yields were computed for each debt issue by dividing the coupon by the end-of-year closing price reported in the Investor's Monthly Manual. The results are presented in Table 10. After sovereign debt defaulters were subject to gunboat diplomacy or lost fiscal sovereignty, yield spreads fell by approximately 800 basis points or 80 percent. $^{22}$ The dramatic decline in yield spreads helps to explain why some earlier studies found that defaulters were not charged significantly higher interest rates than countries that repaid their debts during the gold standard (Lindert and Morton, 1989). By not separating the pre-supersanction period from the supersanction period, country risk was biased downward. Indeed, a simple test of a difference in means finds that the null hypothesis of no change in the yield spread in the pre-supersanction and supersanction periods can easily be rejected at the one- percent level of significance.

An alternative explanation for the significant fall in yield spreads is that the market price of risk declined during the classical gold standard. Indeed, recent studies have pointed to the gold standard, economic policies, and membership in the British Empire as institutional and economic factors that may have promoted financial integration in this earlier period of globalization (Bordo and Rockoff, 1996; Ferguson and Schularick, forthcoming; Flandreau and Zumer, 2004). To account for this alternative explanation, we use Chile as a market control. For the presupersanction and supersanction periods we compare yield spreads for Chile with yield spreads for the sovereign defaulters in our sample. We selected Chile as our emerging market control because the country faithfully repaid its debts during the gold standard period and was relatively stable during this period. Therefore, a decline in the yield spread for Chile should largely reflect a fall in market rather than country risk. Subtracting the yield spread for Chile from the yield spread for each sovereign defaulter for the pre-supersanction and supersanction periods should provide a lower bound estimate of the reduction in default risk. Table 11 shows that even after over-controlling for a decline in market risk, yield spreads fell dramatically for defaulting countries once they were placed under house arrest or subjected to military intervention. The decline in sovereign risk remains statistically significant at the five-percent level.

\footnotetext{
${ }^{22}$ The results of the yield spread analysis are robust to changing the "representative" interest rate for countries with multiple issues trading on the London exchange. We experimented with a variety of issues including ones used by Obstfeld and Taylor (2002), Ferguson and Schularick (forthcoming), and Flandreau and Zumer (2004). The results remained unchanged and are available from the authors by request.
} 
One potential shortcoming of our analysis is the lack of a true counterfactual. One could argue that "supersanctioned" countries might have enacted fiscal reforms that would have revived their capital market reputations in the absence of foreign intervention. While we cannot rule out this possibility, it seems unlikely. Prior to the implementation of supersanctions, countries in our sample spent nearly 47 percent of the gold standard period in default. In contrast, countries spent virtually no time in default after they were supersanctioned. ${ }^{23}$ In addition, countries that surrendered their fiscal sovereignty to external bondholder committees or foreign governments did not default for the remainder of the gold standard period. The fact that we find little statistical evidence of general trade sanctions and the fact that most of the countries in our sample were serial defaulters suggests that sovereign defaulters were unlikely to have enacted the necessary fiscal reforms to repay their debts without supersanctions.

The empirical evidence we have shown suggests that capital markets significantly reevaluated debt that had been supersanctioned. Realized returns were higher and ex ante default risk was lower. Although capital market reputation appears to have improved with the onset of supersanctions, to what extent were resuscitated defaulters able to raise new capital? To provide some perspective on this question, we use Stone's (1999) estimates of government capital-issues floated on the London stock exchange before and after the onset of supersanctions, and supplement his data with information from the Investor's Monthly Manual, which provides data on minor debt issues sold by smaller countries on the London market. Table 12 shows that only countries that surrendered total fiscal sovereignty for an extended period of time (Egypt, Greece, and Turkey) borrowed significant quantities in international capital markets following the onset of supersanctions. Overall, our results suggest that gunboat diplomacy promoted repayment of existing defaulted debt while external financial control over a long period of time promoted debt repayment and allowed countries to regain access to international capital markets.

\section{Private Creditor Sanctions}

\footnotetext{
${ }^{23}$ Nicaragua briefly defaulted in 1912 on debt nominally guaranteed by U.S. authorities under the Roosevelt Corollary. But subsequent intervention by the U.S. in 1912 prodded Nicaragua to come to terms with its creditors. Nicaragua repaid its debts for the remainder of the gold standard period. Costa Rica remained in default even after the announcement of the Roosevelt Corollary and actions by the U.S. government in Santo Domingo that enforced the new U.S. foreign policy in 1904 and 1905. However, Costa Rica arrived at a debt workout with bondholders in 1912 following U.S. threats to take over control of the country's customs houses.
} 
Another option available to private creditors was to seize the assets of sovereign defaulters. There are six clear cases when asset seizure was employed by private creditors as a sanction for debt default (See Appendix A for details). Unlike supersanctions, the seizure of assets by private creditors to settle debt defaults does not seem to have been a very effective sanction for deterring future default. Three out of the six countries that conceded assets to creditors defaulted within a decade after reaching a debt settlement. Ecuador and Costa Rica defaulted multiple times after granting property rights to bondholders. Moreover, the seizure of assets by private creditors does not appear to have supported the issuance of new debt on the London capital market. None of the six countries that ceded property rights to foreign creditors sold significant amounts of new debt on the London capital market after conceding property rights to foreign creditors.

It might be the case that there is some underlying fundamental difference in the countries (some kind of sample selection bias) that explains why supersanctions were more effective at promoting debt repayment than private creditor sanctions during the classical gold standard era. That is, countries that had assets seized by private creditors may have been in greater financial, political, and economic disarray than countries like Egypt, Greece, and Turkey, which had international financial committees to oversee their fiscal policies and tax collection. This does not seem to be the case, however, as both Costa Rica and Santo Domingo (countries that had assets seized by private creditors), were supersanctioned in 1911 and 1905, respectively. Following the onset of supersanctions, these two countries faithfully repaid their debts for the remainder of the gold standard period. President Roosevelt regarded U.S. intervention in Santo Domingo as crucial to restoring the country's fiscal discipline and service of its external debt. The American President also believed that the experience of the San Domingo Improvement Company showed that private creditor solutions to sovereign debt defaults were ineffective in bringing about fiscal reforms and enforcing debt repayment (Veeser, 2003).

\section{Conclusions}

What are the mechanisms used to enforce sovereign debt repayment? This paper provides new answers to this question using debt defaults from the nineteenth and early-twentieth centuries. This early period of globalization provides a unique experiment to test the existence 
and effectiveness of a wide range of debt sanctions including trade credit sanctions, seizure of debtors' assets by creditors, gunboat diplomacy, and international financial control. Contrary to recent studies examining modern defaults, we do not find that, in general, trade fell in response to default. Nor do we find that sanctions applied by private creditors were an effective mechanism for preventing future defaults or cleansing the reputation of defaulters. The enforcement mechanism that seems to have been more important, at least from a sanctions perspective, was the imposition of foreign financial control or gunboat diplomacy.

Contrary to what other scholars have suggested, we find that supersanctions were an effective enforcement mechanism that was employed nearly 30 percent of the time after a sovereign debt default, and on more than 40 percent of all defaulted debt from the gold standard period. The use of gunboats or financial "house arrest" had a significant impact on the reputation of sovereign debtors in the London capital market and appears to have deterred future default. According to data on new debt issues, the ex ante default probability on a principal default decreased by more than 60 percent after a country had been supersanctioned. We also find that a country's risk premium, measured as the yield spread over consols, declined by approximately 800 basis points after the implementation of supersanctions. Countries that gave up fiscal sovereignty for an extended period of time were also able to return and borrow in international capital markets at lower interest rates.

Caballero and Dornbusch (2002) have suggested that third-party financial control of Argentina is the most feasible way for it to restore its reputation in international capital markets. This paper presents evidence that such policies have, in the past, been successful in cleansing the reputation of debtors. Although the sanctions imposed in the nineteenth century are perhaps more radical than what would be feasible or desirable today, our paper nevertheless suggests that some type of fiscal or monetary control by an external financial committee may impose needed discipline on recalcitrant debtors, and help them revive their capital market reputations so they can undertake new borrowing in capital markets. 


\section{References}

Angell, James W. Financial Foreign Policy of the United States. New York: Russell and Russell.

Banks, Arthur S. (1976). “Cross-National Time Series: 1815-1973.” [Computer file]. ICPSR ed. Ann Arbor, MI: Inter-university Consortium for Political and Social Research [producer and distributor].

Barbieri, Katherine. (1996). Economic Interdependence and Militarized Interstate Conflict, 1870-1985. Ph.D. dissertation, SUNY Binghamton.

Borchard, Edwin. (1951). State Insolvency and Foreign Bondholders: General Principles. Vol. 1, Yale University Press: New Haven.

Bordo, Michael D. and Finn Kydland. (1995). "The Gold Standard as a Rule: An Essay in Exploration." Explorations in Economic History 32(4): 423-464.

Bordo, Michael D. and Anna Schwartz. (1995). "The Operation of the Specie Standard-Evidence for Core and Peripheral Countries. In Jorge de Macedo, Barry Eichengreen, and Marc Flandreau. Currency Convertibility: The Gold Standard and Beyond. London: Routledge.

Bordo, Michael D. and Hugh Rockoff. (1996). "The Gold Standard as a 'Good Housekeeping Seal of Approval." Journal of Economic History 56(2): 389-428.

British Board of Trade. Various years. Statistical Abstract for the Principal and other Foreign Countries. London: Board of Trade.

British Board of Trade. Various years. Statistical Abstract for the United Kingdom. London: Board of Trade.

Bulow, Jeremy and Kenneth Rogoff. (1989a). "Sovereign Debt: Is to Forgive to Forget?" American Economic Review 79(1): 43-50.

Bulow, Jeremy and Kenneth Rogoff. (1989b). "A Constant Recontracting Model of Sovereign Debt.” Journal of Political Economy 97(1): 155-78.

Caballero, Ricardo and Rudiger Dornbusch. (2002). "Argentina: A Rescue Plan that Works.” Financial Times Op-Ed (April 8).

Conklin, James. (1998). “The Theory of Sovereign Debt and Spain under Phillip II," Journal of Political 106(3): 483-513.

Corporation of Foreign Bondholders. (Various Years). Annual Report. London: CFB.

Correa, H.M. Alvares. (1926). The International Controls of Public Finances: A Treatise of International Law. Amerstdam: Drukkerij M.J. Portielje.

Davis, Lance and Stanley Engerman. (2003). "Sanctions: Neither War nor Peace." Journal of Economic Perspectives 17(2): 187-197. 
Eaton, Jonathan and Raquel Fernandez. (1995). "Sovereign Debt.” In G. Grossman and K. Rogoff (eds.) Handbook of International Economics. Amsterdam: North-Holland.

Eaton, Jonathan and Mark Gersovitz. (1981). "Debt with Potential Repudiation: Theoretical and Empirical Analysis." Review of Economic Studies 48: 239-309.

English, William B. (1996). "Understanding the Costs of Sovereign Default: American State Debts in the 1840s." American Economic Review 86(1): 259-275.

Ferguson, Niall. (2004a). Colossus: The Price of American Empire. New York: Penguin Press.

Ferguson, Niall. (2004b). "The City of London and British Imperialism: New Light on an Old Question." In Yousef Cassis and Eric Bussiere (eds.) London and Paris as International Financial Centres in the Twentieth Century. Oxford: Oxford University Press.

Ferguson, Niall and Moritz Schularick. (forthcoming). "The Empire Effect: The Determinants of Country Risk in the First Age of Globalization, 1880-1913." New York University, Stern School of Business Working Paper EC-04-03 Journal of Economic History.

Flandreau, Marc and Mathilde Maurel. (2001). "Monetary Union, Trade Integration, and Business Cycles in 19th Century Europe: Just Do It." Centre for Economic Policy Research, Discussion Paper Series No. 3087.

Flandreau, Marc and Frederic Zumer. (2004). The Making of Global Finance. Paris: OECD.

Foreman-Peck, James. (1995). A History of the World Economy: International Economic Relations Since 1850. New York: Harvester.

Fratianni, Michele. (2004). “Government Debt, Reputation, and Creditors' Protection: The Tale of San Giorgio,” Indiana University Business School Working Paper.

Hogan, Albert E. (1906). Pacific Blockades. Oxford: Clarendon Press.

Kaletsky, Anatole. (1985). The Costs of Default. New York: Priority Press Publications and Twentieth Century Fund.

Kletzer, Kenneth M. and Brian D. Wright. (2000). "Sovereign Debt as Intertemporal Barter." American Economic Review 90(3): 621-39.

Lindert, Peter H. and Peter J. Morton. (1989). “How Sovereign Debt Worked.” In Jeffery Sachs (ed.) Developing Country Debt and Economic Performance, vol. 1, pp. 39-106. Chicago: University of Chicago Press.

Ling, Dwight L. (1967). Tunisia: From Protectorate to Republic. Bloomington: Indiana University Press.

Lipson, Charles. (1985). Standing Guard: Protecting Foreign Capital in the Nineteenth and Twentieth Centuries. Berkeley: University of California Press.

Lopez-Cordova, J. Ernesto and Christopher Meissner. (2003). "Exchange Rate Regimes and International Trade: Evidence from the Classical Gold Standard Era." American Economic Review 93(1): 344-353. 
Marichal, Carlos. (1989). A Century of Debt Crises in Latin America. Princeton: Princeton University Press.

Martinez, Jose Vicente and Guido Sandleris. (2004). "Is it Punishment? Sovereign Defaults and the Decline in Trade." Unpublished paper, Columbia University (August).

Mauro, Paolo and Yishay Yafeh. (2003). "The Corporation of Foreign Bondholders." IMF Working Paper 03/107. http://www.imf.org/external/pubs/ft/wp/2003/wp03107.pdf.

Meissner, Chris. (forthcoming). "A New World Order: Explaining the Emergence of the Classical Gold Standard." Journal of International Economics.

Mitchener, Kris James and Marc Weidenmier. (forthcoming). "Empire, Public Goods, and the Roosevelt Corollary.” Journal of Economic History and NBER Working Paper 10279 (September 2004).

Obstfeld, Maurice and Kenneth S. Rogoff. (1996). Foundations of International Macroeconomics. Cambridge: MIT Press.

Obstfeld, Maurice and Alan M. Taylor. (2003). "Sovereign Risk, Credibility, and the Gold Standard: 1870-1913 versus 1925-31." Economic Journal 113(1): 1-35.

Obstfeld, Maurice and Alan M. Taylor. (2004). Capital Markets: Integration, Crisis, and Growth. Cambridge: Cambridge University Press.

Officer, Lawrence. (2004). “The Gold Standard.” EH-Net Encyclopedia Entry. http://www.eh.net/encyclopedia/?article=officer.gold.standard.

Ozler, Sule (1993). "Have Commercial Banks Ignored History?” American Economic Review 83(3): 608620.

Platt, D.C.M. (1968). Finance, Trade, and Politics in British Foreign Policy 1815-1914. Oxford: Oxford University Press.

Reinhart, Carmen M. and Kenneth S. Rogoff. (2004). "Serial Default and the 'Paradox' of Rich to Poor Capital Flows." American Economic Review, Papers and Proceedings 94(2): 53-58.

Rippy, J. Fred. (1934). "The British Bondholders and the Corollary to the Monroe Doctrine." Political Science Quarterly 49(2): 195-206.

Rose, Andrew K. (2002). "One Reason Countries Repay Their Debts: Renegotiation and International Trade.” NBER Working Paper 8853 (March). http://www.nber.org/papers/W8853.

Schneider, Jurgen, et. al., eds. (1991-1997). Wahrungen der Welt, Vol. 1-8. Beitrage zur Wirtschafts-und Sozialgeschichte No. 44-57. Stuttgart: Steiner.

Stone, Irving (1999). The Global Export of Capital From Great Britain, 1865-1913: A Statistical Survey. New York: St. Martin's Press.

Suter, Christain and Hanspeter Stamm. (1992). "Coping with Global Debt Crises Debt Settlements, 1820 to 1896." Comparative Studies in Society and History 34: 645-678. 
Veeser, Cyrus. (2003). "Inventing Dollar Diplomacy: The Gilded-Age Origins of the Roosevelt Corollary to the Monroe Doctrine." Diplomatic History 27(3): 301-326.

Weidenmier, Marc D. (forthcoming). "Gunboats, Reputation, and Sovereign Repayment:

Lessons from the Southern Confederacy, Journal of International Economics.

Wynne, William H. (1951). State Insolvency and Foreign Bondholders. Volume 2. New Haven: Yale University Press.

Ziegler, Philip. (1988). The Sixth Great Power: A History of One of the Greatest of all Banking Families, the House of Barings, 1762-1929. New York: A.A. Knopf. 
Figure 1. Total Defaulted Debt Outstanding: 1877 - 1917

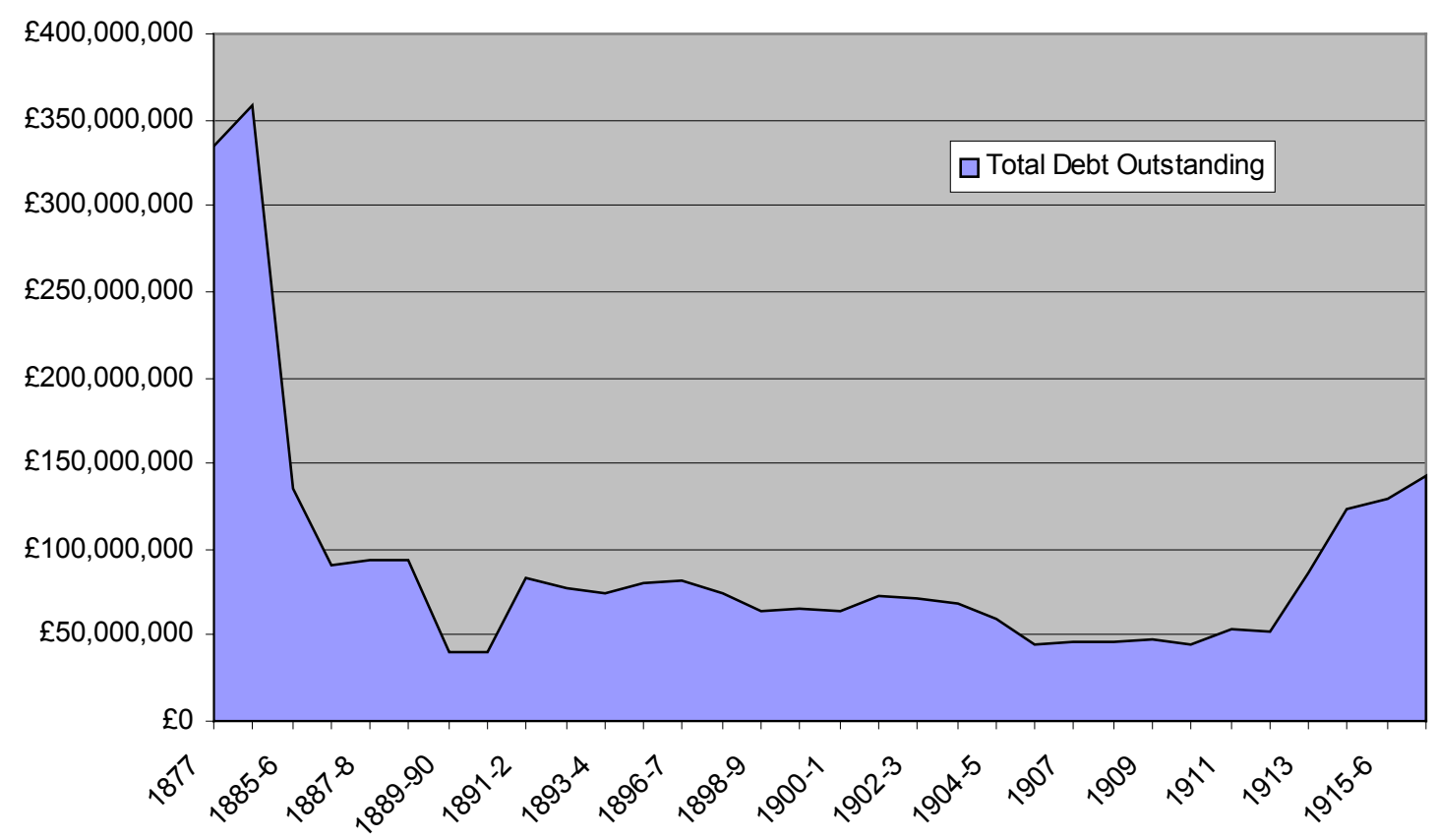

Source: Corporation of Foreign Bondholders, Annual Reports (various issues). 
Table 1. Sovereign Debt Default During the Gold Standard Era

\begin{tabular}{|c|c|c|c|c|c|c|c|c|}
\hline Country & Default & Resumption & Default & Resumption & Default & $\underline{\text { Resumption }}$ & Default & $\underline{\text { Resumption }}$ \\
\hline Argentina & 1890 & 1894 & & & & & & \\
\hline Bolivia & 1878 & 1880 & & & & & & \\
\hline Brazil & 1898 & 1902 & & & & & & \\
\hline Colombia* & 1873 & 1873 & 1879 & 1896 & 1900 & 1905 & & \\
\hline Costa Rica & 1874 & 1886 & 1895 & 1898 & 1901 & 1912 & & \\
\hline Santo Domingo & 1872 & 1889 & 1892 & 1894 & 1897 & 1898 & 1899 & 1907 \\
\hline Ecuador & 1868 & 1890 & 1894 & 1903 & 1906 & 1907 & 1909 & 1911 \\
\hline Egypt & 1876 & 1881 & & & & & & \\
\hline Greece & 1826 & 1880 & 1894 & 1898 & & & & \\
\hline Guatemala & 1875 & 1889 & 1894 & 1896 & 1898 & 1913 & & \\
\hline Honduras & 1873 & 1927 & & & & & & \\
\hline Liberia* & 1874 & 1900 & 1912 & 1912 & & & & \\
\hline Mexico & 1867 & 1887 & & & & & & \\
\hline Morocco* & 1903 & 1904 & & & & & & \\
\hline Nicaragua & 1827 & 1875 & 1894 & 1896 & 1912 & 1912 & & \\
\hline Paraguay & 1874 & 1886 & 1892 & 1897 & & & & \\
\hline Peru & 1876 & 1890 & & & & & & \\
\hline Portugal & 1892 & 1903 & & & & & & \\
\hline Salvador & 1898 & 1900 & & & & & & \\
\hline Servia* & 1895 & 1895 & & & & & & \\
\hline Spain & 1873 & 1876 & & & & & & \\
\hline Tunis & 1867 & 1871 & & & & & & \\
\hline Turkey & 1876 & 1882 & & & & & & \\
\hline Uruguay & 1876 & 1879 & & & & & & \\
\hline Venezuela & 1865 & 1882 & 1898 & 1906 & & & & \\
\hline
\end{tabular}

Sources and notes: Corporation of Foreign Bondholders, Annual Report (various issues), Borchard (1951), and Correa (1926). Turkey refers to the Ottoman Empire.

* Colombia (1873), Servia (1895), Morocco (1903-1904), and Liberia (1912) all had multilateral reschedulings prior to the onset of open default (Suter and Stamm, 1992, p. 651). 
Table 2

Sanctions during the Classical Gold Standard Period, 1870-1913*

\section{Panel A. Supersanctions}

\begin{tabular}{|c|c|c|}
\hline Country & Description of Sanction & Year(s) \\
\hline Costa Rica & $\begin{array}{l}\text { Roosevelt Corollary; } \\
\text { U.S. threatens to take over customs houses }\end{array}$ & 1911 \\
\hline Egypt & $\begin{array}{l}\text { U.K. administers finances } \\
\text { for the Khedive }\end{array}$ & $1881-1913$ \\
\hline Greece & $\begin{array}{l}\text { International financial body administers finances } \\
\text { of the defaulting republic }\end{array}$ & $1898-1913$ \\
\hline Guatemala & $\begin{array}{c}\text { U.K. threatens Guatemala } \\
\text { with gunboats; Guatemala agrees to settle long } \\
\text { outstanding defaulted debts with its creditors }\end{array}$ & 1913 \\
\hline Liberia & $\begin{array}{l}\text { U.S. administers customs houses and imposes debt } \\
\text { restrictions }\end{array}$ & $1912-1913$ \\
\hline Morocco & $\begin{array}{l}\text { International body appointed to oversee customs } \\
\text { houses }\end{array}$ & $\begin{array}{l}\text { 1905-1911 } \\
\text { (followed by the establishment of a } \\
\text { French protectorate in April 1912) }\end{array}$ \\
\hline Nicaragua & $\begin{array}{c}\text { Roosevelt Corollary; } \\
\text { threat of U.S. gunboat diplomacy helps lead to } \\
\text { debt settlement; New York bank administers } \\
\text { converted loan }\end{array}$ & 1912 \\
\hline Santo Domingo & $\begin{array}{c}\text { Roosevelt Corollary; } \\
\text { U.S. administers customs houses }\end{array}$ & $1905-1913$ \\
\hline Servia & $\begin{array}{l}\text { International financial body helps to oversee } \\
\text { country's finances following debt default; foreign } \\
\text { bondholders have less control over Servia finances } \\
\text { than in other instances of financial control }\end{array}$ & $1895-1913$ \\
\hline Tunis & $\begin{array}{c}\text { International financial body administers customs } \\
\text { houses following debt default }\end{array}$ & $\begin{array}{l}\text { 1870-1881 (followed by the } \\
\text { establishment of a French } \\
\text { protectorate) }\end{array}$ \\
\hline $\begin{array}{l}\text { Turkey } \\
\text { (Ottoman } \\
\text { Empire) } \\
\end{array}$ & $\begin{array}{l}\text { International financial body administers customs } \\
\text { houses following debt default }\end{array}$ & $1882-1913$ \\
\hline Venezuela & $\begin{array}{l}\text { International blockade } \\
\text { in response to debt default }\end{array}$ & $1902-1903$ \\
\hline
\end{tabular}

Sources: Angell (1933), Borchard (1951), and Suter and Stamm (1992).

\section{Panel B. Private Creditor Sanctions}

\begin{tabular}{|c|c|c|}
\hline Country & Description of Sanction & Year(s) \\
\hline Costa Rica & Ceded control of some railroad assets to creditors & 1885 \\
\hline Ecuador & Ceded control of some railroad assets to creditors & $1897-1898$ \\
\hline Paraguay & Ceded some land to creditors & 1885 \\
\hline Peru & $\begin{array}{c}\text { Entered into Grace Contract: in return for canceling } \\
\text { defaulted debts, bondholders were given state } \\
\text { railways for 66 years, 2 million tons of guano, 5 } \\
\text { million acres of public lands, and some steamboats }\end{array}$ & $1889-1913$ \\
\hline Salvador & Ceded control of some railroad assets to creditors & 1899 \\
\hline Santo Domingo & Ceded control of some railroad assets to creditors & 1893 \\
\hline
\end{tabular}

Sources: Corporation of Foreign Bondholders, Annual Report (various years), Marichal (1989), Suter and Stamm (1992). 
Table 3

Statistics for Sovereign Debt Defaults and Sanctions, 1870-1913

Panel A. Summary Statistics for Debt Default and Sanctions

\begin{tabular}{|l|c|}
\hline Total number of default episodes & 43 \\
\hline Total number of countries that defaulted & 25 \\
\hline Number of default episodes with any type of sanction & 18 \\
\hline Percent of defaulted debt with any type of sanction & 46 \\
\hline Number of default episodes with a supersanction & 12 \\
\hline Percent of defaulted debt with a supersanction & 40 \\
\hline $\begin{array}{l}\text { Number of default episodes with a private creditor } \\
\text { sanction }\end{array}$ & 6 \\
\hline $\begin{array}{l}\text { Percent of defaulted debt with a private creditor } \\
\text { sanction }\end{array}$ & 6 \\
\hline
\end{tabular}

Panel B. Conditional Probability of a Debt Sanction

\begin{tabular}{|l|c|}
\hline Prob(Any type of sanction| Debt default episode) & $18 / 43=.42$ \\
\hline Prob(Any type of sanction | Country defaulted at least once) & $16 / 25=.64$ \\
\hline Prob(Any type of sanction | Country defaulted more than once) & $9 / 11=.81$ \\
\hline Prob(Supersanction | Debt default episode) & $12 / 43=.28$ \\
\hline Prob(Private creditor sanction | Debt default episode) & $6 / 43=.14$ \\
\hline
\end{tabular}


Table 4: The Effects of Default on Trade, 1870-1913 (Pooled OLS Regressions)

(Dependent Variable: Log of the Average Value of Bilateral Trade)

Default

Lagged Default(-1)

Lagged Default(-2)

Lagged Default(-3)

Log Distance

Log Area

Log Population

Log Railroad Miles

\begin{tabular}{|c|c|c|c|c|}
\hline \multirow{18}{*}{$\begin{array}{l}\text { Column 1 } \\
-1.088^{* * *} \\
(0.066)\end{array}$} & Column 2 & Column 3 & Column 4 & Column 5 \\
\hline & $-0.555^{* * *}$ & $-0.170 * *$ & -0.045 & -0.076 \\
\hline & $(0.101)$ & $(0.078)$ & $(0.079)$ & $(0.074)$ \\
\hline & $-0.226^{* *}$ & $-0.103 *$ & -0.043 & -0.036 \\
\hline & $(0.094)$ & $(0.056)$ & $(0.051)$ & $(0.052)$ \\
\hline & $-0.082 *$ & -0.013 & 0.011 & 0.013 \\
\hline & $(0.044)$ & $(0.034)$ & $(0.033)$ & $(0.034)$ \\
\hline & $-0.542 * * *$ & $-0.198 * * *$ & -0.086 & -0.065 \\
\hline & $(0.097)$ & $(0.073)$ & $(0.077)$ & $(0.078)$ \\
\hline & $-0.423 * * *$ & $-0.334 * * *$ & $-0.288 * * *$ & $-0.264 * * *$ \\
\hline & $(0.108)$ & $(0.090)$ & $(0.081)$ & $(0.080)$ \\
\hline & $0.268 * * *$ & -0.047 & $-0.118 * * *$ & $-0.133 * * *$ \\
\hline & $(0.041)$ & $(0.044)$ & $(0.040)$ & $(0.042)$ \\
\hline & & $0.640 * * *$ & $0.414 * * *$ & $0.389 * * *$ \\
\hline & & $(0.052)$ & $(0.058)$ & $(0.059)$ \\
\hline & & & $0.361 * * *$ & $0.398 * * *$ \\
\hline & & & $(0.045)$ & $(0.051)$ \\
\hline & & & & YES \\
\hline 9696 & 8812 & 8764 & 8764 & 8764 \\
\hline 0.03 & 0.14 & 0.39 & 0.48 & 0.5 \\
\hline
\end{tabular}

Year Dummies

Observations

8812

0.39

0.48

0.5

Standard errors in parentheses

$*$ significant at $10 \% ; * *$ significant at $5 \% ; * * *$ significant at $1 \%$ Note: A constant term was also included (not shown). 
Table 5. Gravity Model of Trade with Default, 1870-1913

(Dependent Variable: Log of the Average Value of Bilateral Trade)

\begin{tabular}{|c|c|c|c|c|}
\hline & Fixed Effects & Random Effects & Fixed Effects & Random Effects \\
\hline \multirow[t]{2}{*}{ Default } & 0.004 & 0.004 & 0.041 & 0.039 \\
\hline & $(0.029)$ & $(0.029)$ & $(0.029)$ & $(0.029)$ \\
\hline \multirow[t]{2}{*}{ Lagged Default(-1) } & -0.048 & -0.047 & -0.04 & -0.042 \\
\hline & $(0.038)$ & $(0.038)$ & $(0.037)$ & (0.038) \\
\hline \multirow[t]{2}{*}{ Lagged Default(-2) } & 0.03 & 0.03 & 0.04 & 0.041 \\
\hline & $(0.039)$ & $(0.040)$ & $(0.039)$ & $(0.040)$ \\
\hline \multirow[t]{2}{*}{ Lagged Default(-3) } & -0.043 & -0.039 & -0.048 & -0.047 \\
\hline & $(0.031)$ & $(0.031)$ & $(0.030)$ & $(0.031)$ \\
\hline \multirow[t]{2}{*}{ Log Area } & $-0.718^{* * *}$ & $-0.329 * * *$ & $-0.210^{* *}$ & -0.05 \\
\hline & $(0.083)$ & $(0.035)$ & $(0.088)$ & $(0.034)$ \\
\hline \multirow[t]{2}{*}{ Log Railroad Miles } & $0.061 * * *$ & $0.100 * * *$ & -0.005 & $0.027 * *$ \\
\hline & $(0.009)$ & $(0.009)$ & $(0.010)$ & $(0.010)$ \\
\hline \multirow[t]{2}{*}{ Log Population } & $1.211 * * *$ & $1.027 * * *$ & $0.574 * * *$ & $0.616^{* * *}$ \\
\hline & $(0.034)$ & $(0.029)$ & $(0.051)$ & $(0.035)$ \\
\hline \multirow[t]{2}{*}{ Log distance } & & -0.005 & & $-0.281 * * *$ \\
\hline & & $(0.096)$ & & $(0.082)$ \\
\hline \multirow[t]{2}{*}{ Common Language } & & $1.180 * * *$ & & 0.329 \\
\hline & & $(0.239)$ & & $(0.206)$ \\
\hline \multirow[t]{2}{*}{ Border } & & $0.733 * *$ & & 0.37 \\
\hline & & $(0.287)$ & & $(0.242)$ \\
\hline \multirow[t]{2}{*}{ Number Landlocked } & & 0.142 & & -0.245 \\
\hline & & $(0.228)$ & & $(0.193)$ \\
\hline \multirow[t]{2}{*}{ Gold Standard } & $0.100 * * *$ & $0.135^{* * *}$ & $0.102 * * *$ & $0.118 * * *$ \\
\hline & $(0.018)$ & $(0.018)$ & $(0.018)$ & $(0.018)$ \\
\hline \multirow[t]{2}{*}{ Currency Union } & 0.119 & 0.185 & -0.131 & 0.029 \\
\hline & $(0.128)$ & $(0.126)$ & $(0.127)$ & $(0.124)$ \\
\hline \multicolumn{3}{|l|}{ Year Dummies } & YES & YES \\
\hline Observations & 8764 & 8764 & 8764 & 8764 \\
\hline Number of dyads & 322 & 322 & 322 & 322 \\
\hline R-squared & 0.39 & 0.38 & 0.42 & 0.36 \\
\hline \multicolumn{5}{|c|}{ Standard errors in parentheses } \\
\hline * significant at $10 \%$; & & at $1 \%$ & & \\
\hline
\end{tabular}


Table 6. A Gravity Model of Trade with Default \& Creditors, 1870-1913

(Dependent Variable: Log of the Average Value of Bilateral Trade)

\begin{tabular}{|c|c|c|c|c|}
\hline & $\begin{array}{l}\text { Fixed } \\
\text { Effects }\end{array}$ & $\begin{array}{l}\text { Random } \\
\text { Effects }\end{array}$ & $\begin{array}{l}\text { Fixed } \\
\text { Effects }\end{array}$ & $\begin{array}{l}\text { Random } \\
\text { Effects }\end{array}$ \\
\hline \multirow[t]{2}{*}{ Default } & -0.031 & -0.032 & 0.001 & -0.001 \\
\hline & $(0.032)$ & $(0.032)$ & $(0.031)$ & $(0.032)$ \\
\hline \multirow[t]{2}{*}{ Lagged Default(-1) } & -0.037 & -0.037 & -0.027 & -0.03 \\
\hline & $(0.041)$ & $(0.041)$ & $(0.040)$ & $(0.041)$ \\
\hline \multirow[t]{2}{*}{ Lagged Default(-2) } & 0.027 & 0.026 & 0.037 & 0.038 \\
\hline & $(0.042)$ & $(0.042)$ & $(0.042)$ & $(0.042)$ \\
\hline \multirow[t]{2}{*}{ Lagged Default(-3) } & $-0.054 *$ & -0.053 & $-0.058^{*}$ & $-0.060 *$ \\
\hline & $(0.033)$ & $(0.033)$ & $(0.033)$ & $(0.033)$ \\
\hline \multirow[t]{2}{*}{ Default w/Creditor } & $0.208 * *$ & $0.211 * *$ & $0.237 * * *$ & $0.239 * * *$ \\
\hline & $(0.081)$ & $(0.082)$ & $(0.080)$ & $(0.081)$ \\
\hline \multirow[t]{2}{*}{ Lagged Default w/Creditor(-1) } & -0.066 & -0.058 & -0.079 & -0.069 \\
\hline & $(0.111)$ & $(0.112)$ & $(0.109)$ & $(0.111)$ \\
\hline \multirow[t]{2}{*}{ Lagged Default w/Creditor(-2) } & 0.01 & 0.013 & 0.006 & 0.006 \\
\hline & $(0.117)$ & $(0.118)$ & $(0.114)$ & $(0.116)$ \\
\hline \multirow[t]{2}{*}{ Lagged Default w/Creditor(-3) } & 0.052 & 0.068 & 0.041 & 0.058 \\
\hline & $(0.089)$ & $(0.090)$ & $(0.087)$ & $(0.089)$ \\
\hline \multirow[t]{2}{*}{ Log Area } & $-0.719 * * *$ & $-0.327 * * *$ & $-0.212^{* *}$ & -0.049 \\
\hline & $(0.083)$ & $(0.035)$ & $(0.088)$ & $(0.034)$ \\
\hline \multirow[t]{2}{*}{ Log Railroad Miles } & $0.064 * * *$ & $0.103^{* * *}$ & -0.003 & $0.029 * * *$ \\
\hline & $(0.009)$ & $(0.009)$ & $(0.011)$ & $(0.010)$ \\
\hline \multirow[t]{2}{*}{ Log Population } & $1.206^{* * *}$ & $1.020 * * *$ & $0.568 * * *$ & $0.611 * * *$ \\
\hline & $(0.034)$ & $(0.029)$ & $(0.051)$ & $(0.035)$ \\
\hline \multirow[t]{2}{*}{ Log Distance } & & -0.008 & & $-0.283 * * *$ \\
\hline & & $(0.095)$ & & $(0.082)$ \\
\hline \multirow[t]{2}{*}{ Common Language } & & $1.179 * * *$ & & 0.33 \\
\hline & & $(0.238)$ & & $(0.207)$ \\
\hline \multirow[t]{2}{*}{ Border } & & $0.731 * *$ & & 0.371 \\
\hline & & $(0.285)$ & & $(0.242)$ \\
\hline \multirow[t]{2}{*}{ Number Landlocked } & & 0.14 & & -0.248 \\
\hline & & $(0.226)$ & & $(0.193)$ \\
\hline \multirow[t]{2}{*}{ Gold Standard } & $0.101 * * *$ & $0.137 * * *$ & $0.103 * * *$ & $0.119 * * *$ \\
\hline & $(0.018)$ & $(0.018)$ & $(0.018)$ & $(0.018)$ \\
\hline \multirow[t]{2}{*}{ Currency Union } & 0.116 & 0.183 & -0.136 & 0.024 \\
\hline & $(0.128)$ & $(0.126)$ & $(0.126)$ & $(0.124)$ \\
\hline Year Dummies & & & YES & YES \\
\hline Observations & 8764 & 8764 & 8764 & 8764 \\
\hline Number of dyads & 322 & 322 & 322 & 322 \\
\hline R-squared & 0.39 & 0.23 & 0.42 & 0.36 \\
\hline
\end{tabular}

Standard errors in parentheses

* significant at $10 \%$; * significant at 5\%; *** significant at $1 \%$ Note: A constant term as well as common language, common border, and the number of landlocked countries were also included (not shown). 
Table 7. A Gravity Model of Trade with Supersanctions, 1870-1913

(Dependent Variable: Log of the Average Value of Bilateral Trade)

Default

Lagged Default(-1)

Lagged Default(-2)

Lagged Default(-3)

Default with Creditor

Lagged Default w/Creditor(-1)

Lagged Default w/Creditor(-2)

Lagged Default w/Creditor(-3)

Log Area

Log Railroad Miles

Log Distance

Roosevelt Corollary

Venezuela Incident

Turkey Revenue Collection

Greek Revenue Collection

Egyptian Revenue Collection
Fixed Effects Random Effects

$-0.005 \quad-0.004$

(0.031) (0.032)

$-0.03 \quad-0.031$

$(0.040) \quad(0.041)$

$0.037 \quad 0.039$

(0.041) (0.042)

$-0.046 \quad-0.05$

(0.033) (0.033)

$0.208 * * * \quad 0.214 * * *$

(0.080) (0.081)

$-0.09 \quad-0.077$

(0.109) (0.111)

$0.007 \quad 0.007$

(0.114) (0.116)

$0.049 \quad 0.062$

(0.087) (0.089)

$-0.368 * * * \quad-0.056 *$

(0.096) (0.034)

$-0.003 \quad 0.029 * * *$

(0.011) (0.010)

$-0.280 * * *$

(0.082)

$-0.368 * * * \quad-0.347 * * *$

(0.071) (0.072)

$-0.362 * * \quad-0.333 * *$

(0.150) (0.153)

$-0.303 * * * \quad-0.083$

(0.103) (0.091)

$-0.169 * * \quad-0.186 * * *$

$(0.068) \quad(0.070)$

$-0.624 * * * \quad-0.533 * * *$

(0.161) (0.163)

$\begin{array}{lrr}\text { Observations } & 8764 & 8764 \\ \text { Number of dyads } & 322 & 322 \\ \text { R-squared } & 0.43 & 0.36\end{array}$

Standard errors in parentheses

$*$ significant at $10 \% ; * *$ significant at $5 \% ; * * *$ significant at $1 \%$

Notes: A constant term as well as common language, common border, number of landlocked countries, the log product of population, gold standard, and currency union variables were also included (not shown). 
Table 8

Ex Ante Default Probabilities Before and After the Onset of Supersanctions (Percent)

\begin{tabular}{|c|c|c|c|c|}
\hline & \multicolumn{2}{|c|}{ Interest-Only Default } & \multicolumn{2}{c|}{ Default on Principal } \\
\hline Country & $\begin{array}{c}\text { Before } \\
\text { Supersanction }\end{array}$ & $\begin{array}{c}\text { Supersanction } \\
\text { period }\end{array}$ & $\begin{array}{c}\text { Before } \\
\text { Supersanction }\end{array}$ & $\begin{array}{c}\text { Supersanction } \\
\text { period }\end{array}$ \\
\hline Costa Rica & 61.4 & 41.4 & 4.8 & 2.1 \\
\hline Egypt & 58.4 & 17.3 & 4.4 & .6 \\
\hline Greece & 51.7 & 25 & 3.1 & 1.1 \\
\hline Nicaragua & 47.4 & 54 & 2.9 & 3.3 \\
\hline Turkey & 60.3 & 37.4 & 4.9 & 1.7 \\
\hline $\begin{array}{c}\text { Unweighted } \\
\text { Average }\end{array}$ & 57.4 & 33.6 & 4.3 & 1.6 \\
\hline
\end{tabular}

Notes: Prior to the implementation of supersanctions, we found data on IPO prices for 25 debt issues: Costa Rica(2), Egypt(4), Greece(6), Nicaragua(1), and Turkey(12). We found data on IPO prices for 17 debt issues after the onset of supersanctions: Costa Rica(1), Egypt(2), Greece(5), Nicaragua(2), and Turkey(7). Nicaragua is included in the sample because the issuance of new debt was nominally backed by the Roosevelt Corollary. The Costa Rica issue included in the supersanction sample was a refunding issue that called for the establishment of external financial control in the event of default. Removing these two countries from the sample does not change the results.

Table 9

Ex Ante Default Probabilities Before and After the Onset of Supersanctions (Percent)

\begin{tabular}{|c|c|c|}
\hline & \multicolumn{2}{|c|}{ Percent Change in Default Probability } \\
\hline Country & Interest-Only Default & Default on Principal \\
\hline Costa Rica & -32.5 & -55.8 \\
\hline Egypt & -70.5 & -86.4 \\
\hline Greece & -51.2 & -63.9 \\
\hline Nicaragua & 13.8 & 12.1 \\
\hline Turkey & -37.9 & -66.0 \\
\hline $\begin{array}{c}\text { Unweighted } \\
\text { Average }\end{array}$ & -42.0 & -63.0 \\
\hline
\end{tabular}

Test of differences in means: $p$-value $=0.05$ for both an interest-only default and a default on principal. 
Table 10. Yield Spreads for Supersanctioned Sovereign Debt (Percent)

\begin{tabular}{|c|c|c|}
\hline Country & Before Supersanction & Supersanction Period \\
\hline Costa Rica & 29.15 & 7.69 \\
\hline Egypt & 5.63 & 1.60 \\
\hline Greece & 16.87 & 7.64 \\
\hline Guatemala & 13.72 & 8.87 \\
\hline Nicaragua & 6.34 & 4.88 \\
\hline Turkey & 6.86 & 1.80 \\
\hline Venezuela & 16.26 & 2.84 \\
\hline Unweighted Average & 16.02 & 4.02 \\
\hline
\end{tabular}

Test of differences in means: $\mathrm{p}$-value $=0.01$

Notes: This table computes the interest rate on sovereign bonds minus the rate on the British consol for countries that faced gunboat diplomacy or loss of fiscal sovereignty. The computed measure reflects the ex post change in "country risk" for sovereign debt. For Costa Rica, Guatemala, Nicaragua, and Venezuela, we calculated yield spreads from the announcement of the Roosevelt Corollary until the end of the gold standard period. As pointed out in Mitchener and Weidenmier (forthcoming), bond traders largely capitalized the effect of U.S. intervention on debt prices in 1904-1906.

\section{Table 11. Yield Spreads for Supersanctioned Sovereign Debt Controlling for Reduction in Market Risk (Percent)}

\begin{tabular}{|c|c|c|}
\hline Country & Before Supersanction & Supersanction Period \\
\hline Costa Rica & 26.61 & 6.05 \\
\hline Egypt & 2.65 & -0.53 \\
\hline Greece & 14.32 & 5.67 \\
\hline Guatemala & 10.70 & 7.23 \\
\hline Nicaragua & 4.02 & 3.24 \\
\hline Turkey & 3.90 & -0.30 \\
\hline Venezuela & 13.72 & 1.20 \\
\hline Unweighted Average & 13.43 & 2.08 \\
\hline
\end{tabular}

Test of differences in means: $p$-value $=0.01$

Notes: This table computes the yield spreads as the interest rate for country i minus the interest rate on the British consol and country risk for Chile that over-controls for the decline in market risk during the gold standard period. The computed measure reflects the ex post change in "country risk" for sovereign debt. 
Table 12

\section{Government Capital Issues on the London Exchange Before and After the Onset of Supersanctions, 1870-1913 (Millions of Pound Sterling)}

\begin{tabular}{|c|c|c|}
\hline Country & Before Supersanction & Supersanction Period \\
\hline Costa Rica & 3.4 & 0.0 \\
\hline Egypt & 5.75 & 8.40 \\
\hline Greece & 9.45 & 3.55 \\
\hline Guatemala & 0.5 & 0.0 \\
\hline Liberia & 0.2 & 0.0 \\
\hline Nicaragua & 0.26 & 1.0 \\
\hline Santo Domingo & 0.757 & 0.0 \\
\hline Servia & 0.0 & 0.0 \\
\hline Turkey & 17.58 & 6.48 \\
\hline Venezuela & 2.5 & 0 \\
\hline
\end{tabular}

Notes: Costa Rica issued approximately 1.4 million pounds in 1911 on the Paris Bourse. Servia did not issue government debt on the London exchange. The country had approximately 15.765 million pounds of external debt when the country rescheduled its debt service with creditors in 1895. Most of its external debt was sold on the Paris and St. Petersburg exchanges. Venezuela and Santo Domingo converted existing debts into a single issue following the onset of supersanctions. These loans consolidated existing debts (that included some debts not issued on the London Exchange) and interest in arrears and did not result in a transfer of resources from capital markets. Tunis had approximately 11 million pounds $(275,000,000$ francs $)$ of debt outstanding when it defaulted in 1867 (Ling, 1967, p.18). The country did not borrow again from international markets until the French government extended a loan to the Bey of Tunis after the country had been established as a protectorate of the European power. Morocco borrowed approximately 2.5 million pounds from French bankers up until the rescheduling of its debts in 1903-1904. The North African country borrowed an additional 4 million pounds with the Loan of 1910 (Correa, 1926, pp.98-101).

Sources: Stone (1999), Investor's Monthly Manual, and London Stock Exchange Yearbook. 


\section{Appendix A. Private Creditor Sanctions during the Classical Gold Standard Era}

Perhaps the most famous episode is the Peruvian debt settlement of 1889 , known as the Grace Contract. In exchange for canceling Peru’s \$30 million debt and \$23 million dollars of interest in arrears, foreign creditors received control of Peru's railways for 66 years, two tons of guano, five million acres of public lands, and a steamship line on Lake Titicaca. In Costa Rica, Minor Keith, an American citizen, arranged a debt settlement between the government and foreign bondholders for the 1 million pound (1871) and the 2.4 million pound (1872) loans. The defaulted debt was funded into a new "Consolidated External debt" issue with series "A" and "B" after a 50-percent haircut. Mr. Keith agreed to pay interest on the two new debt obligations from 1886 until 1888. In return, the government paid the interest in arrears on the defaulted debt by giving shares of the Costa Rica Railway Company to investors (Corporation of Foreign Bondholders, Annual Report, various years). The government also ceded control of 600,000 acres of public lands to promote the construction of additional railroads. Costa Rica later defaulted on the converted debt in the mid-1890s.

Other Caribbean and Latin American countries ceded railway rights to bondholders. In 1893, Santo Domingo defaulted on its 1888 and 1890 loans floated primarily in continental Europe. The 1890 issue was floated to finance the construction of a railroad from Puerto Plata to Santiago. The loan was guaranteed by (1) a mortgage on the first section of the line, (2) an annual subsidy of 24,000 pounds for 56 years, and (3) receipts on the first section of the line, a mortgage on the second, and rolling stock (Corporation of Foreign Bondholders, Annual Report, various years). Following the debt default, American creditors purchased the defaulted bonds and established the San Domingo Improvement Company to manage the country's debts and railroad assets acquired as part of the debt settlement. The agreement worked until the San Domingo Improvement Company defaulted on interest payments to European bondholders in 1897 (Veeser, 2003). Dominican President Ulysses Heureux was assassinated two years later, the country fell into a deep recession, and civil war broke out. This was subsequently followed by American intervention in 1904-1905 in order to restore order and pay off international creditors.

European bondholders also received railroad assets as part of an 1897-1898 debt

agreement with Ecuador. Bondholders of Ecuador received stock in the Guayaquil and Quito Railway Company in exchange for assuming the external debts of the country. The debt 
settlement did not appear to be very effective, however, as the country defaulted on its external debt several times prior to the outbreak of World War I.

In 1899, El Salvador came to an agreement with its creditors and turned over ownership of the country's railroads to the Salvador Railway Company. In return, the firm agreed to service government debts issued in 1889 and 1892 and to complete a railway line to the capital by June 30, 1900. The agreement remained in effect for the remainder of the gold standard period.

Similar measures were taken in Paraguay to settle debt defaults. In 1885, the government of Paraguay agreed to concessions in exchange for a reduction in its external debt from three million pounds to 800,000. The Asuncion government ceded 2.2 million acres of public lands and forests to the Corporation of Foreign Bondholders. Foreign bondholders established the Anglo-Paraguay Land and Cattle Company, which played an important role in Paraguay's economy over the next 30 years (Marichal, 1989). 


\section{Appendix B. Gravity Models without Currency Correction}

Appendix Table 1: The Effects of Default on Trade, 1870-1913

(Dependent Variable: Log of the Average Value of Bilateral Trade)

\begin{tabular}{|c|c|c|c|c|c|}
\hline & Column 1 & Column 2 & Column 3 & Column 4 & Column 5 \\
\hline \multirow[t]{2}{*}{ Default } & $-1.018 * * *$ & $-0.564 * * *$ & $-0.261 * * *$ & $-0.148^{*}$ & $-0.154 * *$ \\
\hline & $(0.067)$ & $(0.097)$ & $(0.075)$ & $(0.077)$ & $(0.070)$ \\
\hline \multirow[t]{2}{*}{ Lagged Default(-1) } & & $-0.164 * *$ & -0.051 & 0.012 & 0.026 \\
\hline & & $(0.072)$ & $(0.057)$ & $(0.057)$ & $(0.059)$ \\
\hline \multirow[t]{2}{*}{ Lagged Default(-2) } & & -0.056 & -0.018 & 0.005 & 0.006 \\
\hline & & $(0.043)$ & $(0.034)$ & $(0.033)$ & $(0.033)$ \\
\hline \multirow[t]{2}{*}{ Lagged Default(-3) } & & $-0.514 * * *$ & $-0.208 * * *$ & -0.092 & -0.081 \\
\hline & & $(0.094)$ & $(0.078)$ & $(0.081)$ & $(0.084)$ \\
\hline \multirow[t]{2}{*}{ Log Distance } & & $-0.407 * * *$ & $-0.335 * * *$ & $-0.290 * * *$ & $-0.276^{* * *}$ \\
\hline & & $(0.105)$ & $(0.094)$ & $(0.085)$ & $(0.084)$ \\
\hline \multirow[t]{2}{*}{ Log Area } & & $0.279 * * *$ & 0.016 & -0.051 & -0.064 \\
\hline & & $(0.039)$ & $(0.044)$ & $(0.042)$ & $(0.043)$ \\
\hline \multirow[t]{2}{*}{ Log Population } & & & $0.540 * * *$ & $0.300 * * *$ & $0.286 * * *$ \\
\hline & & & $(0.053)$ & $(0.060)$ & $(0.061)$ \\
\hline \multirow[t]{2}{*}{ Log Railroad Miles } & & & & $0.383 * * *$ & $0.410 * * *$ \\
\hline & & & & $(0.044)$ & $(0.050)$ \\
\hline Year Dummies & & & & & YES \\
\hline Observations & 9781 & 8896 & 8848 & 8848 & 8848 \\
\hline R-squared & 0.02 & 0.14 & 0.32 & 0.43 & 0.44 \\
\hline
\end{tabular}

Standard errors in parentheses

* significant at $10 \% ; * *$ significant at $5 \%$; ** significant at $1 \%$

Note: A constant term was also included (not shown). 
Appendix Table 2. Gravity Model of Trade with Default, 1870-1913

(Dependent Variable: Log of the Average Value of Bilateral Trade)

\begin{tabular}{|c|c|c|c|c|}
\hline & Fixed Effects & Random Effects & Fixed Effects & Random Effects \\
\hline \multirow[t]{2}{*}{ Default } & -0.034 & -0.031 & 0.017 & 0.02 \\
\hline & $(0.039)$ & $(0.039)$ & $(0.038)$ & $(0.039)$ \\
\hline \multirow[t]{2}{*}{ Lagged Default(-1) } & -0.011 & -0.006 & 0.007 & 0.009 \\
\hline & $(0.050)$ & $(0.051)$ & $(0.050)$ & $(0.051)$ \\
\hline \multirow[t]{2}{*}{ Lagged Default(-2) } & 0.035 & 0.032 & 0.044 & 0.041 \\
\hline & $(0.052)$ & $(0.053)$ & $(0.052)$ & $(0.053)$ \\
\hline \multirow[t]{2}{*}{ Lagged Default(-3) } & -0.053 & -0.043 & -0.047 & -0.045 \\
\hline & $(0.041)$ & $(0.041)$ & $(0.040)$ & $(0.041)$ \\
\hline \multirow[t]{2}{*}{ Log Area } & $0.416^{* * *}$ & $-0.268 * * *$ & $1.098 * * *$ & 0.007 \\
\hline & $(0.114)$ & $(0.038)$ & $(0.120)$ & $(0.035)$ \\
\hline \multirow[t]{2}{*}{ Log Railroad Miles } & $0.053 * * *$ & $0.131 * * *$ & 0.016 & $0.066^{* * *}$ \\
\hline & $(0.012)$ & $(0.011)$ & $(0.013)$ & $(0.013)$ \\
\hline \multirow[t]{2}{*}{ Log Population } & $1.522 * * *$ & $1.185 * * *$ & $0.777 * * *$ & $0.702 * * *$ \\
\hline & $(0.043)$ & $(0.036)$ & $(0.062)$ & $(0.039)$ \\
\hline \multirow[t]{2}{*}{ Log distance } & & -0.068 & & $-0.337 * * *$ \\
\hline & & $(0.100)$ & & $(0.084)$ \\
\hline \multirow[t]{2}{*}{ Common Language } & & $1.794 * * *$ & & $0.792 * * *$ \\
\hline & & $(0.249)$ & & $(0.212)$ \\
\hline \multirow[t]{2}{*}{ Border } & & $0.654^{* *}$ & & 0.333 \\
\hline & & $(0.297)$ & & $(0.246)$ \\
\hline \multirow[t]{2}{*}{ Number Landlocked } & & 0.277 & & -0.214 \\
\hline & & $(0.236)$ & & $(0.197)$ \\
\hline \multirow[t]{2}{*}{ Gold Standard } & -0.038 & 0.005 & -0.025 & -0.016 \\
\hline & $(0.024)$ & $(0.024)$ & $(0.024)$ & $(0.024)$ \\
\hline \multirow[t]{2}{*}{ Currency Union } & 0.087 & 0.21 & -0.105 & 0.128 \\
\hline & $(0.169)$ & $(0.165)$ & $(0.167)$ & $(0.162)$ \\
\hline \multicolumn{3}{|l|}{ Year Dummies } & YES & YES \\
\hline Observations & 8848 & 8848 & 8848 & 8848 \\
\hline R-squared & 0.37 & 0.35 & 0.39 & 0.32 \\
\hline \multicolumn{5}{|c|}{ Standard errors in parentheses } \\
\hline * significant at $10 \% ; *$ & $-\infty$ & & & \\
\hline
\end{tabular}

